\title{
1 A review of source tracking techniques for fine sediment within a catchment
}

2

4

5

6

7

8

9

Zhuo Guan $\bullet$ Xiang-Yu Tang $•$ Jae E. Yang $\bullet$ Yong Sik Ok $\bullet$ Zhihong Xu $\bullet$ Taku Nishimura $\bullet$ Brian

J. Reid

Zhuo Guan • Xiang-Yu Tang $(\bowtie)$

Key Laboratory of Mountain Surface Processes and Ecological Regulation, Institute of Mountain Hazards and Environment, Chinese Academy of Sciences, Chengdu 610041, China

e-mail: xytang@imde.ac.cn

Tel: +86 28 85213556; fax: +8628 85222258

Jae E. Yang $(\varangle) \cdot$ Yong Sik Ok

School of Natural Resources and Environmental Science \& Korea Biochar Research Center, Kangwon National University, Chuncheon 24341, Korea

e-mail: yangjay@kangwon.ac.kr

Tel: +8233250 6446; fax: +82332416640

Taku Nishimura $(\bowtie) \cdot$ Zhuo Guan

Laboratory of Soil Physics and Soil Hydrology, Department of Biological and Environmental Engineering, Graduate School of Agricultural and Life Sciences, the University of Tokyo, Tokyo 113-8657, Japan

e-mail: takun@soil.en.a.u-tokyo.ac.jp 
25 Zhihong Xu

26 Environmental Futures Research Institute, School of Natural Sciences, Griffith University, Nathan,

27 Brisbane, Queensland 4111, Australia

28

29 Brian J. Reid

30 School of Environmental Sciences, University of East Anglia, Norwich NR4 7TJ, UK 
31

\section{Abstract}

Excessive transport of fine sediment, and its associated pollutants, can cause detrimental impacts in aquatic environments. It is therefore important to perform accurate sediment source apportionment to identify hotspots of soil erosion. Various tracers have been adopted, often in combination, to identify sediment source type and its spatial origin, these include: fallout radionuclides, geochemical tracers, mineral magnetic properties and bulk and compound-specific stable isotopes. In this review, the applicability of these techniques to particular settings and their advantages and limitations are reviewed. By synthesizing existing approaches, that make use of multiple tracers in combination with measured changes of channel geomorphological attributes, an integrated analysis of tracer profiles in deposited sediments in lakes and reservoirs can be made. Through a multi-scale approach for fine sediment tracking, temporal changes in soil erosion and sediment load can be reconstructed and the consequences of changing catchment practices evaluated. We recommend that long-term, as well as short-term, monitoring of riverine fine sediment and corresponding surface and subsurface sources at nested sites within a catchment are essential. Such monitoring will inform the development and validation of models for predicting dynamics of fine sediment transport as a function of hydro-climatic and geomorphological controls. We highlight, that the need for monitoring is particularly important for hilly catchments with complex and changing land-use. We recommend that research should be prioritized for sloping farmland-dominated catchments.

Keywords Fine sediment • Tracking techniques $\bullet$ Source identification $\bullet$ Temporal markers $\bullet$ Mixing models 


\section{Introduction}

Selective soil erosion and sediment transport, leading to downstream fining and an enrichment of organic matter content along sediment cascades have been well recognized at the catchment scale (Koiter et al. 2015). Field evidence, reported more than 30 years ago from the Jackmoor Brook catchment $\left(9.8 \mathrm{~km}^{2}\right)$ in Devon, England, indicated that particle size controls selective erosion and transport; with the finest sediment fraction (diameter $<1 \mu \mathrm{m}$ ) exhibiting a delivery ratio of $100 \%$ and coarser sediment (diameter 20-63 $\mu \mathrm{m}$ ) exhibiting a delivery ratio of only 30\% (Walling 1983). Fine sediment is a leading cause of impairment of waterways, particularly lowland rivers, in many countries around the world (Palmer et al. 2000; Grabowski and Gurnell 2016). Natural or anthropogenic disturbances (e.g., damming, agricultural practices, deforestation or timber harvests, urban, suburb or rural development, construction activities and wildfires) are the main causes of excessive fine sediment production and loading to rivers (Collins et al. 2010b; Jones and Schilling 2011).

Various adverse impacts are associated with excessive fine sediment ( $<63 \mu \mathrm{m}$ or fine silt and clay) loads in the aquatic environment and these have led to an increasing concern for catchment management. Excessive amounts of fine sediment can increase turbidity, limit light penetration and potentially reduce photosynthesis and primary productivity of macrophytes. This damages aquatic habitats in the hyporheic zone (e.g., reduction in invertebrate biodiversity and changes in macrophyte communities) (Wood and Armitage 1997; Bo et al. 2007; Kemp et al. 2011) and important game fisheries (e.g., reduced feeding, impaired respiration, physiological stress and migration inhibition) (Collins and Walling, 2007). In great excess, sediment can smother the entire 
stream bed and eliminate habitat complexity (Walser and Bart 2006). The chemically reactive nature of suspended fine sediment makes it a potential vehicle for transporting contaminants (e.g., agrochemicals, antibiotics, persistent organic pollutants, trace metals and metalloids) rapidly over a long distance with streamflow (Horowitz 1991; Zhang et al. 2015). Therefore, fine sediment, either suspended, re-suspended or deposited, in the channel system represents a significant diffuse pollution issue, and one that requires the attention of regulators to ensure safeguards are included within catchment management regulations.

Conventional measures for dealing with excessive fine sediment accumulation in channels, such as riverbed dredging and flushing, are largely impractical for large scale management due to high labor and investment requirements. For different hydro-climatic conditions and catchment characteristics, suitable measures should be developed and implemented along the main transport pathways from source areas to a catchment's outlet (Mukundan et al. 2012; Vinten et al. 2014; Lamba et al. 2015a). The precise design of effective fine sediment management and control policies relies heavily on the quantitative identification of erosion sources, spatial soil redistribution on slopes, in-channel sediment delivery flux and their temporal variation at a given location within the catchment (Shackle et al. 1999; Walling et al. 2003). Knowledge of hydrological processes and the spatial pattern of soil redistribution across the landscape (from slopes to catchment outlet), which can change within a year and between years, is essential to apportioning fine sediment to surface and subsurface sources. Generally, there are five main processes defined in a fine sediment tracking framework, these are: (1) hillslope erosion, (2) gully erosion and deposition, (3) channel bank erosion, (4) channel bed deposition/re-suspension and (5) fine sediment export at catchment outlet (Bartley et al. 2007). The assessment of these processes is limited by our ability to resolve their 
intrinsic spatial and temporal variability at the catchment scale (Grabowski and Gurnell 2016). With the aid of remote sensing and GIS technology, spatial distribution of soil erosion and sediment transport within a catchment can be estimated and erosion prone areas can be identified (Bhattarai and Dutta, 2007; Ganasri and Ramesh 2016). In particular, specific remote sensing data, such as color and standard reflectance spectra derived satellite images, can be used in combination with other in situ physical, optical and acoustic measurements to reveal the dispersal, transport path and fate of fine sediment across coastal margins as well as rivers (Warrick 2009; Loisel et al. 2014; Qu 2014). Remote sensing data are generally limited to the surface layer and are not as accurate as in situ measurements. These limitations can be compensated, to some extent, by the spatial and temporal coverage provided by remote sensing observations, particularly at large scales. However, the available approaches that combine remote sensing data and GIS with soil erosion and sediment transport models remain only moderately successful in reliably predicting (with high resolution) spatial patterns of soil erosion and deposition and the dynamics of sediment transport in channels. Most of the models such as USLE, and its revised forms, do not have the capability for routing sediment through channels. Data on contributions from different sediment source types or erosion processes to sediment are very limited because sediment production from many sediment sources or erosion processes cannot be readily or directly measured in a catchment (Zhang and Liu 2016). The use and development of various tracking techniques allow quantitative identification of the sources of deposited and suspended sediment observed at a concerned location. The majority of existing source tracking studies focus specifically on fine fraction of bulk sediment that is eroded from the surface of diffuse upland areas and channel banks.

While recent reviews have considered the development of sediment source tracking techniques 
and their application (e.g., Walling 2005, 2013; Davis and Fox 2009; Mukundan et al. 2012; Guzman et al. 2013; Haddadchi et al. 2013; Smith et al. 2013) very recent developments, included, in particularly, those relating to anthropogenic origin tracers have not been reviewed. Furthermore, the principles and potential technical framework for combining existing approaches, at different temporal and spatial scale, have not been fully established nor elaborated upon. Given the promise such an integrated approach would have, for fine sediment source apportionment at multiple scales in a catchment, this review seeks to highlight the possibilities. In this review, we revisit the topic and evaluate the strengths and limitations of existing tracking techniques for fine sediment and justify the need for future research directed towards sloping, farmland dominated, catchments.

\section{Selection of sediment source tracers}

In the past five to six decades, a number of tracers, or diagnostic properties, have been successfully used to track sediment sources and quantify their relative contributions within a catchment. These include artificial radionuclides (Brown et al. 1981a,b; Owen et al. 2012), naturally occurring radionuclides (Wallbrink and Murray 1993), deliberately introduced radionuclides (Toth and Alderfer 1960; Wooldridge 1965), geochemical elements (Olley and Caitcheon 2000; Haddadchi et al. 2014), rare earth elements (Tian et al. 1994), bulk stable isotopes (Fox and Papanicolaou 2007), compound-specific stable isotopes (Gibbs 2008), metals (Blake et al. 2012), fluorescent dye coated particles (Young and Holt 1968), magnetic minerals (Yu and Oldfield 1989), color (Grimshaw and Lewin 1980), plant pollen (Brown 1985) and diffuse reflectance infrared Fourier transform spectroscopy (Poulenard et al. 2012). Although these tracers are useful, each has its limitations. In 
this review, we have considered several factors of relevance to the use of a particular tracer, these are: origin, applicable timeframe, applicable spatial scale, advantages and limitations. How a given tracer performs in these regards has been summarized in Table 1. The readers may find it useful to refer to Table 1 when they make use of this review. In practice, the selected tracers need to be easily detectable by readily available analytical instruments.

The use of a composite fingerprint comprising several selected tracers or diagnostic properties has proven to be reliable (Collins et al. 1997a,b; Carter et al. 2003; Krause et al. 2003). Multipletracer approaches may provide information on sediment redistribution and offer a distinct advantage over single tracer approaches. Multiple-tracer approaches are based on two assumptions (Walling et al. 1999): (1) the fingerprints consist of selected diagnostic tracers, these are conservative during sediment delivery and show distinctive differences between major source materials; and (2) comparing the tracers or fingerprints of suspended sediment with those of potential sources leads to quantitative estimation of the relative contribution of each individual source. At a given location, in addition to the net deposition, the relative upslope source contributions to deposited sediment can be quantified based on multiple-tracer measurements. Likewise, for areas of net soil erosion, offsite fate of the mobilized sediment can be tracked; including, where the sediment is redeposited downslope and how much is exported out of the catchment (Polyakov et al. 2004).

It is important to test for normality before proceeding with the selection of tracers. The statistical representation of a tracer's spatial variation within each source area affects the results of sediment source apportionment. By fitting normal distributions to source groups (Krause et al. 2003; Wilkinson et al. 2009), using standard errors for estimated means (Hancock et al. 2014) or median and a robust scaling estimator $\left(Q_{\mathrm{n}}\right)$ (Rousseeuw and Croux 1993), source soils may be represented 
162

163

by the mean concentration derived from spatially random sampling locations in the catchment (Peart and Walling 1986). Catchment-specific nature of tracer spatial variations can be defined using sample data showing representative distributions (Caitcheon et al. 2012; Olley et al. 2013). The statistical verification of a composite fingerprint, comprising multiple tracers, can be performed using principal components analysis (PCA), genetic algorithm-driven discriminant function analysis (GA-DFA) and the Kruskal-Wallis H-test (KW-H) or the Mann-Whitney U-test in combination. Through the application of these statistical approaches the abilities of selected tracers for discriminating spatially the sediment sources can be evaluated (Collins et al. 1997a,b,2012). If a source type shows large differences among sub-catchments for each individual tracer, instead of using a single set of tracers for the whole catchment, statistical analysis should be performed to identify a subset of tracers that could discriminate the sources within each sub-catchment (Walling 2005; Smith et al. 2013). For example, a geochemical composite fingerprinting approach for identifying statistically robust fingerprints was successfully used to apportion channel bed sediment sources in the upper Kennet agricultural catchment $\left(\sim 214 \mathrm{~km}^{2}\right)$ in southern England (Collins et al. 2012). Optimum composite fingerprints were identified for each of the six bed sediment sampling periods using a revised statistical procedure combining GA-DFA, KW-H and PCA and the numerical mass balance mixing model described by Collins et al. (2010b).

\section{Mixing models, correction/weighting factors and uncertainty}

When a set of composite fingerprints comprising $n$ appropriate conservative tracer(s) has been selected to discriminate $>(n+1)$ sources, multivariate mixing (or unmixing) models consisting of a 
184

set of linear equations could be used to determine relative contributions from each source (e.g., Collins et al. 1997a,b; Walden et al. 1997). There are three main types of mixing models: mixing model without uncertainty terms in the mixing equations (Eq. 1; Collins et al. 1997a,b,) or mixing models with uncertainty terms in mixing equations that are accommodated by Bayesian (Eq. 2; Franks and Rowan 2000) or Monte Carlo approaches (Eq. 3; Hughes et al. 2009).

The mixing model without uncertainty term can be written as:

$$
\sum_{s=1}^{m} P_{S} S_{i, s}=C_{i} \quad \text { with } i=1, n \text { and } \sum_{s=1}^{m} P_{s}=1
$$

where $C_{i}$ is the concentration of fingerprint tracer $i$ in sediment sample, $P_{s}$ is the optimized percentage contribution from source $s, S_{i, s}$ is median concentration of tracer $i$ in source $s$ with or without particle size and organic matter corrections, $n$ is number of fingerprint tracers and $m$ is the number of sediment sources.

An uncertainty-inclusive Bayesian mixing model can be written as:

$$
\sum_{s=1}^{m} P_{S} S_{i, s}=C_{i}+\varepsilon_{i} \quad \text { with } i=1, n \text { and } \sum_{s=1}^{m} P_{s}=1
$$

where $\varepsilon_{i}$ is the error associated with the prediction of the target tracer value $C_{i}$.

The Hughes model (Hughes et al. 2009) applies a Monte Carlo approach and runs random iterations of all individual source samples (not their mean) to minimize the errors. This is obviously different from the Collins and FR2000 (Franks and Rowan 2000) methods, that both use mean values for each tracer parameter pertaining to each source. The Hughes model can be written as:

$$
\sum_{l=1}^{1000} \sum_{s=1}^{j} P_{S} S_{i, s, k, l} / 1000=C_{i} \quad i=1, n
$$

where $j$ is sample number index, each sample has $k$ constituent concentrations and $l$ is Monte Carlo iteration number.

As given in Eqs. 1-3, for each tracer, a linear equation is used to relate tracer concentration in fine 
sediment to the sum of each source's tracer concentration multiplied by unknown relative contribution from each source. By minimizing differences between estimated tracer properties/concentrations in fine sediment and those measured using an objective function (e.g., the sum of relative errors or the squares of errors), each source's contribution can be obtained (e.g., Collins et al. 1997a,b).

The goodness-of-fit of the model can be assessed by comparing the actual tracer properties/concentrations measured in fine sediment with the corresponding values estimated by the optimized mixing model (Collins et al. 2010b). Many mathematical tools (e.g., MATLAB, Mathematica and Excel) have built-in programs that can be used to solve these quadratic programming problems. The Monte Carlo or Bayesian simulation could be employed to quantify uncertainty associated with sampling and source estimates (e.g., Small et al. 2002; Caitcheon et al. 2012), either explicitly in mixing equations or separately. It is also essential to include particle size correction factors, organic matter content correction factors, which are often site-specific, withinthe source variability and discriminatory power of each tracer, (Collins et al. 1997; Collins et al. 2010b). In particular, particle size effects are due to preferential adsorption of some tracers to fine particles and selective transport that may cause a difference in particle size distribution between source soil and fine sediment (Smith et al. 2013). Particle size corrections based on specific surface area ratios, analysis of the fine fraction of suspended sediment, or thorium normalization could be used to minimize particle size effects on tracer properties/concentrations (e.g., Collins et al. 1997a,b; Wallbrink et al. 1999; Foucher et al. 2015). The hypothesis of positive linearity between particle size and tracer concentration may not hold true for all tracers, or may differ between different tracers, and precise relationship between particle size composition and tracer concentration for each tracer 
must be routinely tested and developed for individual tracers if the linearity exists (Russell et al. 2001; Smith and Blake 2014). A minimum number of potential sources and a maximum number of composite fingerprints, each with a minimum number of non-contradictory tracers, have been strongly recommended (Zhang and Liu 2016). However, source apportionment results may relate to fine fraction and may not provide information on sources of bulk suspended sediment load.

The largest uncertainties of model prediction are often found in downstream sub-catchments, which are usually the main contributors of fine sediment. Subsurface erosion of river bank occurs mostly in downstream reaches (Theuring et al. 2015). Catchment-wide spatial variation of each fine sediment source type has rarely been evaluated. Sampling location of sediment (e.g., headwaters and downstream sections) affects the estimated contributions of sources, which are dependent on the spatial and temporal variations in runoff generation.

Software tools have been developed for sediment source apportionment based on mixing models and isotopic tracer measurements, such as, IsoSource (Phillips and Greg 2003), SIAR (Parnell et al. 2010) and CSSIAR (Sergio et al. 2017). IsoSource allows entering only one sediment mixture and ten potential sources at the same time, and is not applicable for investigating large areas with different sediment mixtures and sources. As an advantage over IsoSource, SIAR incorporates uncertainties using a Bayesian approach. Therefore, SIAR has been more successful with wider applications, using not only isotopic tracers but also other tracers or diagnostic properties such as geochemical and radionuclide tracers and color (Parnell et al. 2010; Dutton et al. 2013; Koiter et al. 2013a; Barthod et al. 2015). Both IsoSource and SIAR require users to make some calculations (e.g., methanol correction for fatty acid methylesters, calculation of source soil proportions from isotopic proportion) before and after the model runs. CSSIAR is a newly available open source tool based 
on the Bayesian approach of SIAR for sediment source apportionment using $\delta^{13} \mathrm{C}$ values of compound specific stable isotopes (e.g., fatty acids and other tracer compounds), in which all calculations are included and performed via a user-friendly interface (Sergio et al. 2017).

\section{Sampling of source soil and fine sediment}

Random or grid sampling of source soil focuses on potential source types (Wallbrink et al. 1998;

Fox 2005). Primary sources can be identified by investigating erosion-prone areas (i.e., sites showing erosion scars and sparse vegetative cover and potentially connected to the channel network), hydrologic processes and sediment delivery/redistribution paths in sub-catchments (Collins and Walling 2007).

Taking into account geological, topological and hydrological variability, replicates should be collected in each of the potential source areas including upland surface soils, river beds and banks and other sources (e.g., construction sites and road verges) to ensure representativeness of tracer datasets. In particular, repeated sampling of sources will be essential if ${ }^{7} \mathrm{Be}$ (a cosmogenic tracer with a short half-life of 53.3 days) is to be used for tracking temporal changes in sediment sources associated with runoff events or other human (e.g., land-use change and plowing) and natural interferences (e.g., fire) (Smith et al. 2013).

Suspended sediment in channels at gaging stations can be monitored and sampled using an automatic water sampler triggered by water-level variations. Samples of water and bulk surface sediment at different locations on channel beds can be collected using a cylinder following the procedure proposed by Lambert and Walling (1988). The depth of fine sediment ingress in channel 
272 bed varies temporally and spatially, normally of the order of 1-10 cm (e.g., Frostick et al. 1984;

273 Collins and Walling 2007; Grabowski and Gurnell 2016). Therefore, a sampling depth of ca. $5 \mathrm{~cm}$

274 into the channel bed is recommended. The water and sediment enclosed within sampling cylinders

275 are thoroughly mixed to re-suspend and collect fine sediment. Fine sediment recovered from bulk

276 surface sediment collected from a riparian area, a channel bed, a dam reservoir or a floodplain can

277 be used as surrogates for suspended fine sediment that is representative of a longer period of

278 deposition (Olley and Caitcheon 2000; Foster et al. 2007; Haddadchi et al. 2013). It should be noted

279 that the sources of suspended sediment may differ from that of recovered fine fraction of deposited

280 sediment (Nicholls 2001). Tracer data pertaining to the fine fraction of deposited sediment should

281 be applied carefully into source apportionment models, with accommodation made to incorporate

282 correction factors that account for differences in particle size selectivity between sediment delivery

283 and sediment deposition processes.

284 Fine sediment can be recovered from bulk surface water or re-suspended sediment by settling and

285 subsequent centrifugation, followed by freeze-drying and homogenization using a $63 \mu \mathrm{m}$ sieve. A

286 composite sample is prepared by mixing all individual samples to obtain a sufficient amount of fine

287 sediment (e.g., 2-50 g) for analyses of radionuclides and other tracer properties or concentrations.

288 Other than water samplers used for rain event based monitoring, bed sediment samplers can be used as an alternative means of collecting fine sediment undergoing continuous remobilization.

290 These are particularly useful for investigating seasonal patterns (Philips et al. 2000). Time-

291 integrated samples of suspended sediment have recently become more popular while point sampling

292 at specific times throughout the hydrograph of a runoff event (i.e., rising and falling limbs) may be conducted in order to pinpoint erosion processes that vary temporally. It should be noted that, time- 
integrated sampling approach requires correction or additional sediment concentration samples to estimate total suspended sediment because time-integrated samplers usually show sediment trapping efficiencies lower than 100\% (Phillips et al. 2000). Point sampling approach is limited by the large volume of sample required for tracer analysis (Davis and Fox 2009).

Localized spatial variations in fine sediment storage on a channel bed are dependent on the variability of water depth, channel sinuosity and bed morphology (Collins and Walling 2007). Thus, it is desirable for sampling campaigns that collect suspended and deposited sediment to be complemented by surveys to define these attributes (Evrard et al. 2011).

\title{
Strengths and limitations of tracers
}

\author{
Radionuclides
}

Fallout radionuclides (e.g., ${ }^{137} \mathrm{Cs},{ }^{7} \mathrm{Be}$ and ${ }^{210} \mathrm{~Pb}_{\mathrm{ex}}$ ) are generally abundant in surface soil (particularly in association with fine particles) but are sparse in subsurface soil (Wallbrink and Murray 1993; He and Walling 1996). Thus, they can be used to differentiate erosion of surface soil from that of deeper sub-soil. ${ }^{137} \mathrm{Cs}$ and ${ }^{210} \mathrm{~Pb}_{\text {ex }}$ have been extensively used to trace surface and subsurface sources of sediment suspended or deposited in river channels, reservoirs and lakes. Estimates of sediment delivery and sedimentation using ${ }^{137} \mathrm{Cs}$ and ${ }^{210} \mathrm{~Pb}$ ex have proven to be consistent (Shi et al. 2012). The two radionuclides generate comparable results with data collected using more traditional approaches (e.g., erosion pins, runoff plots and the monitoring of catchment sediments yields) (e.g., Elliott et al. 1990; Mabit et al. 2002) and empirical erosion models (e.g., the 
USLE and RUSLE models) (Mabit et al. 2008). As the traditional approaches cannot account for uncertainties while upscaling the results, the use of the two radionuclides has the advantage of determining spatial variations in soil erosion and sediment deposition across the landscape as well as for specific landscape elements (Mabit et al. 2008). ${ }^{137} \mathrm{Cs}$ and ${ }^{210} \mathrm{~Pb}$ ex can be used to distinguish sediment eroded from uncultivated and cultivated lands (Wallbrink et al. 1998). Cosmogenic ${ }^{7} \mathrm{Be}$ is usually concentrated in top $5 \mathrm{~mm}$ of soil. Thus, ${ }^{7} \mathrm{Be}$ can be used to discriminate very thin surface soil layer from deeper layers and to confirm the relative importance of recently mobilized surface soil due to its very short half-life of 53.3 days, as compared to ${ }^{137} \mathrm{Cs}$ (half-life $30.2 \mathrm{yr}$ ) and ${ }^{210} \mathrm{~Pb}_{\mathrm{ex}}$ (half-life $22.3 \mathrm{yr}$ ) (Zapata 2003). ${ }^{7} \mathrm{Be}$ can be used to track sediment redistribution only in cases where no significant erosive rainfall events have occurred for the past 5 months. This significantly limits its application (Walling 2013a). ${ }^{137} \mathrm{Cs}$ and ${ }^{210} \mathrm{~Pb}_{\mathrm{ex}}$ have been extensively included as a tracer within the multivariate models to not only discriminate subsurface versus surface and cultivated versus uncultivated sediment source in soil redistribution studies on slopes (Busacca et al. 1993; Nagle et al. 2000), but also to reconstruct a chronological record of sediment deposition by using cores extracted from floodplains, lakebeds and reservoir beds (Collins et al. 1997a; Hasholt et al. 2000; Zhang et al. 2007). Overall, fallout radionuclides can be the best available fine sediment tracers for source discrimination if relevant correction/weighing factors are incorporated in model estimation where necessary.

\section{Geochemical tracers}

A number of geochemical tracers including rare earth elements (REE; e.g., La, Ce, Pr, Nd, Sm, Eu, 
Gd, Tb, Dy, Ho, Er, Tm, Yb and Lu), major elements (e.g., Fe, K, Na, Al, Ca and Mg) and trace elements (e.g., As, Ba, Co, Cr, Cs, Hf, Sc, Ta, Ti, Th and Zr), in both source soil and sediment samples, have been used in sediment fingerprinting studies (Horowitz et al. 2012). Eroded sediments often maintain these distinct geochemical properties during transport processes (Hughes et al. 2009). Major element geochemistry, particularly the relationship between $\mathrm{Fe}_{2} \mathrm{O}_{3}$ and $\mathrm{Al}_{2} \mathrm{O}_{3}$, can be used to discriminate soils derived from different parent rocks (Dyer et al. 1996).

Active REE tracking method involves artificial mixing REE, normally as oxide powders, with soils at different topographical positions, and sediment transport flux and loss of source materials can be determined by analyzing REE concentrations in sediments (Tian et al. 1994; Zhu et al. 2010).

In very acidic soils, REEs may be partly leached and thus redistributed via desorption and adsorption, limiting their applicability for tracking sediment movement (Land et al. 1999). Furthermore, large errors may be introduced when REE is applied in light-textured soils due to their poor aggregate-forming abilities (Zhang et al. 2001; Kimoto et al. 2006).

At undisturbed/uncultivated sites, physical properties such as water permeability and anti-erosion ability of soil may be changed greatly due to artificial mixing of REE with soil. Therefore, REEderived data cannot truly reflect erosion process of originally undisturbed soil, and thus the applicability of REE tracer method for uncultivated land is restricted (Polyakov et al. 2004). This method may not be suitable for complex natural topographies because within-field deposition is ignored (Zhu et al. 2010).

A non-intrusive method of spraying REE oxide powder suspension to soil surfaces has been proposed to minimize soil surface disturbance (Deasy and Quinton 2010). It has been shown to be effective on a temperate arable hillslope and may also be applicable to temperate grassland, 
rangeland and semi-arid areas. Notably, in karst areas in southwest China, natural geogenic REE signatures were found to be a potential proxy for identifying lacustrine sediment sources and soil erosion rates (Wen et al. 2014). To date, the use of REE tracer methods has been limited, partly due to its relatively high cost.

The use of geochemical tracers, particularly large numbers of major and trace elements, has become increasingly common since the late 1990s (Rollinson 1993; Grimes et al. 2007; Franz et al. 2013). This can be partly attributed to recent advances in both quick analytical techniques for large numbers of samples and numerical source apportioning models that allow a more detailed and quantitative understanding of the uncertainty associated with estimated results. Fine sediment is usually rich in clay minerals, $\mathrm{Fe}$ and $\mathrm{Mn}$ oxides and hydroxides and organic matter. There are three approaches that can account for potential differences in sediment geochemistry relating to particle size and mineralogy. One commonly used way of normalization is to use measured bulk concentrations in the total sediment sample to account for differences in sediment geochemistry. The diluting effects of non-reactive constitutes (e.g., coarse sediment, quartz and feldspar grains) can be removed. The second way of normalization is to divide the concentration of the potential tracer by the concentration of the conservative element (e.g., $\mathrm{Al}$, Ti and $\mathrm{Li}$ ). The third method is to incorporate a correction factor into the mixing model (Collins et al. 1998). Moreover, the geochemical tracer method can also be applied to contemporary and historic sedimentary deposits for reconstructing temporal changes in sediment provenance at the catchment scale (Thevenon et al. 2013).

Properties of organic matter 
383 Soil organic matter cycling that couples soil, plants and the atmosphere through biogeochemical

384 processes results in differences in total organic carbon (TOC), total organic nitrogen (TON) and

385 total organic phosphorus (TOP) between land-uses (e.g., forest and agriculture) (Collins et al.

386 1997b). TOC, TON, TOP and carbon to nitrogen ratio (C/N), either individually, collectively or in

387 combination with other tracers, have been used to represent plant cover, land-use and land

388 management at sediment sources (Collins et al. 1997b; Walling and Amos 1999; Carter et al. 2003;

389 Papanicolaou et al. 2003; Fox and Papanicolaou 2007). Fluorescence excitation-emission matrix

390 (EEM) spectra of sediment leachate can be resolved into fluorescent components using parallel

391 factor analysis (PARAFAC). A novel combined use of fluorescence spectroscopy and end-member

392 mixing analysis (EMMA) was proposed for source discrimination of fine sediment that is often rich

393 in organic matter (Larsen et al. 2015). Fluorescence EEM spectra could provide insightful

394 information on quality of organic matter that differ between sediment sources.

395 Stable isotopes of organic carbon (i.e., $\delta^{13} \mathrm{C}$ ) and nitrogen (i.e., $\delta^{15} \mathrm{~N}$ ) show greater potential 396 detection sensitivity than total elemental composition and therefore can be useful tools to identify 397 sources and sinks of sediments (Papanicolaou et al. 2003; Alewell et al. 2008; Fox and Papanicolaou 398 2007; Turnbull et al. 2008). Soil depth profiles of stable isotopes $\left(\delta^{13} \mathrm{C} v s \% \mathrm{C}\right.$ and $\left.\delta^{15} \mathrm{~N} v s \% \mathrm{~N}\right)$ 399 may be used as qualitative indicators of soil erosion. The $\delta^{13} \mathrm{C}$ measurements can reflect the 400 differences in contributions of different land-uses (e.g., forest, grassland and cropland) to sediments, 401 resulting from the differences in $\delta^{13} \mathrm{C}$ value between $\mathrm{C} 3$ and $\mathrm{C} 4$ plants (Balesdent et al. 1988). Bulk $\delta^{13} \mathrm{C}$ signatures may be strongly affected by past crop rotations or other organic carbon sources such as applications of manure and wastewater (Tang et al. 2014). The stable isotope ratio of nitrogen 
$\left(\delta^{15} \mathrm{~N}\right)$ can be employed to discriminate subsurface sources (e.g., streambanks and construction sites)

of suspended sediment (Fox et al. 2010). High levels of $\delta^{15} \mathrm{~N}$ in cultivated soils and streambanks complement well with the relatively low ${ }^{137} \mathrm{Cs}$ activities detected in these sources (Mukundan et al. 2010; 2012). Future work should be conducted to temporally and spatially identify the hydrologic and biogeochemical controls on the isotopic signatures of surface and subsurface source soils, suspended fine sediment and channel bed sediments where a significant portion of deposited fine sediment is temporarily stored (Mukundan et al. 2012).

Although geochemical properties, radionuclides, anthropogenic pollutants and bulk stable isotopes have been increasingly used to inform the need and effective strategies to control fine sediment erosion (e.g., Collins et al. 2010b), the application of sediment source tracking techniques has its limitations. For example, the use of these approaches cannot give quantitative information on sediment source with specific crop, which is crucial in agriculture-dominated catchments. Gibbs (2008) demonstrated that the use of compound-specific stable isotopes (CSSI) (e.g., $\delta^{13} \mathrm{C}$ of fatty acids) allowed the identification and apportionment of sediment to source soils under different landuses or cropping systems in New Zealand. The plant-produced fatty acids (FA), particularly those having an even number of carbon atoms (C14:0 to C24:0, range of lipid numbers in the form C:D where $\mathrm{C}$ is the number of carbon atoms and $\mathrm{D}$ is the number of double bonds), can be readily leached from leaves and roots and bound strongly to soil particles which may be subsequently transported to channels by water erosion (Williams et al. 2006). Isotopic fractionation of carbon leads to a range of isotopic values for each FA. Acid group of FAs in sediment and source soil samples should be replaced by a methyl group to form a non-polar fatty acid methyl ester (FAME) prior to performing analysis with GC-combustion-IRMS. Different plants or crops produce the same FAs which show 
427 different $\delta^{13} \mathrm{C}$ values in soil under maize (-25.7\%o) and pasture (-30.1\%o) (Blake et al. 2012).

428 Selected FAs are chemically conservative and the $\delta^{13} \mathrm{C}$ value of FAs does not change over time

429 during sediment transport (Blessing et al. 2007). The $\delta^{13} \mathrm{C}$ signatures of fatty acids associated with particles can therefore be used to track sediment in rivers back to uplands under specific vegetation or crop cover. This method could provide unique insights into the development processes of sediment source fingerprinting (Blake et al. 2012). Palmitic (C16:0) and Oleic (C18:1) acids exhibit larger differences across different land-uses and have been reported to be the most useful in source fingerprinting (Gibbs 2014). Myristic acid (C14:0) may also be a good tracer but it is sometime missing in old sediments due to its volatilization. It has been reported that shorter chain FAs can be degraded preferentially by soil microorganisms (Matsumoto et al. 2007). Thus, the dynamics of influencing factors that may affect the results of fine sediment source tracing. Given these dynamic factors the use of CSSI fingerprinting needs careful consideration if it is to be applied meaningfully at different temporal and spatial scales. Furthermore, the CSSI approach is often not a 'standalone' quantitative approach, and complementary tracer data or information are highly desirable (e.g., measured sediment loads in channels, modelled sediment loads within geographical information system, climate/meteorological data and estimates of erosion and sedimentation rates e.g. based on

444 fallout radionuclide measurements). CSSI tracer approaches have been mostly used in contemporary 
Anthropogenic pollutants

Increased concentrations of various anthropogenic contaminants (e.g., persistent organic pollutants, heavy metals and pesticides) discharged into aquatic environments have been reported during the last 200 years (Takeda et al. 2004; Bravo-Espinoza et al. 2009; Tang et al. 2014). Provided that, dates of benchmark events (e.g., first introduction, marked increased or decreased inputs to the environment and/or ban on production and use of the chemicals) are known it is possible to use contaminant profiles of deposited sediment to reconstruct the temporal changes of soil erosion and sediment transport at the catchment scale (Hom et al. 1974; Latimer and Quinn 1996; Middelkoop 2002; Hartmann et al. 2005).

Heavy metals (e.g., $\mathrm{Pb}, \mathrm{Hg}, \mathrm{Zn}$ and $\mathrm{Cu}$ ) are the best recorded anthropogenic contaminants due to high affinity to fine sediment (Chillrud et al. 2003; Franz et al. 2013). In addition, persistent organic pollutants (POPs) (e.g., polychlorinated biphenyls, polycyclic aromatic hydrocarbons, dichlorodiphenyltrichloroethane, benzotriazoles and alkylbenzenes) are ubiquitous in aquatic sediment (Helm et al. 2011). Pesticides may be useful in separating agricultural soils from other types of land-use/land-cover. Sources of fine sediment may be apportioned into individual agricultural fields according to pesticide fingerprints and particle size distribution (Tang et al. 2014). More reliable and detailed information about temporal changes in sedimentation rate and contributing sources over periods of decades can be obtained by inter-comparison and combined use of different dating markers such as radionuclides, heavy metals, persistent organic pollutants, stable isotopes and optically stimulated luminescence (Fox et al. 1999; Boonyatumanond et al. 2007; Hobo et al. 2010). However, it should be noted that most successful studies have been limited to 
lake and estuary sediments, where sedimentation conditions are more ideal than river sediments where stronger physical mixing, resuspension and bioturbation have been reported to disturb the top few centimeters of sediment. At stream gaging stations, it is often not practical to take a large volume of water using an automatic water sampler and this limitation constrains the mass of anthropogenic micropollutants (associated with suspended fine sediment) ultimately collected. This then restricts the opportunity to reliably quantify the presence and concentrations of micropollutants in the sample. Therefore, some of these micropollutants (e.g., organic micropollutants) may not be suitable to be used for tracking sources of fine suspended particles transported during individual rain events. Alternatively, contaminant profiles of deposited sediment at slower moving section of channels and other surface water bodies can be used to apportion sources and reveal temporal variations, despite the inherent limitations relating to selective transport of sediment that is dependent on hydro-climate condition and channel geomorphological characteristics.

Recent studies have shown that stable isotopes of metal contaminants (e.g., $\mathrm{Cd}, \mathrm{Cu}, \mathrm{Hg}$ and $\mathrm{Zn}$ ), in terms of isotopic ratios such as ${ }^{114} \mathrm{Cd} /{ }^{110} \mathrm{Cd},{ }^{65} \mathrm{Cu} /{ }^{63} \mathrm{Cu},{ }^{202} \mathrm{Hg} /{ }^{198} \mathrm{Hg}$, and ${ }^{66} \mathrm{Zn} /{ }^{64} \mathrm{Zn}$, may hold particular promise to track sources of contaminated sediments (Gao et al. 2008; Petit et al. 2008; Weiss et al. 2008; Mil-Homens et al. 2013). However, the use of these 'non-traditional' isotopes is complicated by multiple physical and biological fractionation processes that occur during contaminant transport and following sediment deposition (Wombacher et al. 2004; Rehkämper et al. 2011). At present, these non-traditional metal isotopes may play only a supportive role to complement data obtained using other well established sediment source tracking techniques.

Mineral magnetics 
493 Mineral magnetic properties have been used to discriminate sources of fine sediment entering lakes,

494 rivers and estuaries (Walden et al. 1997; Walling 2013a, b; van der Waal et al. 2015). In particular,

495 mineral magnetics have been successfully used to trace sediment sourced from burned landscapes.

496 In these landscapes fine-grained ferrimagnetic minerals are accumulated in surface soil (Longworth

497 et al. 1979; Smith et al. 2013). Changes in oxidation/reduction conditions in surface soil during

498 burning can convert less magnetic iron oxyhydroxides into more magnetic minerals (Clement et al.

499 2011). Mineral magnetic properties have shown potential for discriminating soil burned at different

500 severities with respect to unburned areas. For example, recent application in the South African

501 Karoo found good discrimination between the sedimentary sources (soils and subsurface material)

502 and dolerite soils due to the much higher magnetism of dolerite soils. Moreover, it was recommended that further fractionation of the $<32 \mu \mathrm{m}$ fraction or a narrower particle size range (e.g., $<10 \mu \mathrm{m})$ should be performed to separate fine sediment $(<63 \mu \mathrm{m})$ and larger particle size fractions of soils and sediments, so that more reliable correction factors can be obtained (Pulley and Rowntree 2016a).

Physical properties

Color signature and particle size distribution were among the earliest tracers developed (Davis et al. 2009). Sediment color, which represents the spectral response of its components (i.e., iron oxides, organic matter, water molecules and clay minerals) to visible light, is an inexpensive tracer despite 
determined using an ordinary color scanner. The uncertainties of color measurement resulting from organic matter and particle size can be minimized by sample pre-treatment with $\mathrm{H}_{2} \mathrm{O}_{2}$ and separating the sediments into two size fractions (Pulley and Rowntree 2016b). Moreover, variations in sediment moisture content and chemical reactions of particles with natural elements can alter the color of the sediment during transport and storage. Therefore, color signature has been less frequently used in recent years. Notably, color parameters measured by Diffuse Reflectance Infrared Fourier Transform Spectroscopy (DRIFTS) can be used to characterize potential sources of suspended sediment in rivers (Martínez-Carreras et al. 2010; Poulenard et al. 2012). For example, in the Galabre $\left(20 \mathrm{~km}^{2}\right)$ catchment (French Southern Alps), DRIFTS and a chemometric technique (i.e., partial least square analysis) were used in parallel to estimate the contribution of potential sources (i.e., molasse, manly limestones, black marls and gypsum) to the sediment flux during the floods (Poulenard et al. 2012). In addition, the use of DRIFT allows direct quantification of the gypsum proportion in soils and sediments (Böke et al. 2004; Poulenard et al. 2012). This method requires only a small amount of sediment contained on filter paper. Both near-infrared and midinfrared spectroscopy, which are quantitatively linked to geochemical properties, could be employed to rapidly characterize fine sediment sources. Particle size distribution is applicable to sediments of heavily contrasting textural origins but may be subject to aggregation or disaggregation during transport. Particle size distribution has been applied for correction purposes rather than for tracing (Collins et al. 1997b).

Other tracers 
The multi-scale, complex and stochastic nature of sediment production, delivery and transport processes complicates the diagnosis of fine sediment sources, pathways and impacts (Grabowski and Gurnell 2016). Geochemical tracers, fallout radionuclides (FRNs) and mineral magnetic properties are the most extensively used for tracking sources of fine sediment (D'Haen et al. 2012). Most of tracers reviewed above may not be applicable for evaluating the effects of recent changes of land use on the relative contributions of sources to fine sediment. Alternatively, active approaches that make use of tracers injected into sources, such as fluorescent fine sediment surrogates (e.g., Harvey et al. 2012) and radioisotope-tagged particles (e.g., ${ }^{56} \mathrm{Fe},{ }^{134} \mathrm{Cs}$ and ${ }^{60} \mathrm{Co}$; Wooldridge 1965 ; Newbold et al. 2005; Greenwood 2012). These have been proposed for evaluating the reach-scale (i.e. $100 \mathrm{~m}$ scale) effect caused by such short-term changes. Using artificial radionuclides for tracking the transport of fine sediment requires radioisotope permits and adequate facilities to store and dispose of radioactive waste. Therefore, the application of artificially introduced radiotracers in the field has been limited.

In addition to these tracers, there are some temporal markers (i.e., benchmark events with known dates), such as forest fire, flood and construction activity, that can be identified with related properties and used to separate the erosion history into several periods showing likely different sedimentation rates (Hobo et al. 2010; Zhang et al. 2012; van der Waal et al. 2015). For example, in the sediment profile at the Jiulongdian Reservoir, southwest China, a thin charcoal layer (2-3 mm thick, observed at $21 \mathrm{~cm}$ depth) marked a forest fire in 1998 and has been used as an additional temporal marker (Zhang et al. 2012). Combined use of these temporal markers and suitable fingerprint tracers could provide information on temporal changes in relative contributions of sources to deposited sediment. 


\section{Aspects of channel morphology, discharge and sedimentology}

560

561

562

563

564

565

566

567

568

569

570

571

572

573

574

575

576

577

578

579

Fine sediment deposition usually occurs in slower moving sections where slopes are less steep, in wetlands, riparian zones and along channel margins. Channel cross sections and longitudinal surveys can be conducted using an automatic level to determine channel morphology and morphometrics (i.e., channel cross-sectional area, bankfull width and depth, width-to-depth ratio and bed slope) (Wethered et al. 2015). Sedimentological units such as benches, bars and channel beds at regular intervals can be sampled for determining the amount of unconsolidated sediment stored within the channel (Collins and Walling 2007). The average thickness of soft fine sediment for each channel transect can be calculated, which is then averaged for the selected transects in a reach. The volume of fine sediment deposition in each reach can then be estimated by multiplying the average thickness of fine sediment by the average channel width and the reach length. Flow velocity, bankfull discharge and unit stream power can be estimated from the morphometric data using standard equations. Geomorphic units, bank sediment profiles, riparian vegetation and Manning's $n$ (roughness) coefficient should also be recorded for each reach. Usually, the sediment sample is sieved through $63 \mu \mathrm{m}$ and the $>63 \mu \mathrm{m}$ fraction is further dry sieved at specific size intervals to determine the size distribution. This in-channel information can be used to quantitatively evaluate seasonal or inter-annual variation in sediment delivery and deposition along the channel pathways with respect to geomorphological and hydro-climate controls. In a survey of 230 streams in agricultural catchments across England and Wales, total fine sediment in channel beds showed a highly significant relationship with stream power (calculated for bankfull flow and used to index 
580

581

582

583

584

585

586

587

588

589

590

591

592

593

594

595

596

597

598

599

600

601

the capacity of the stream to transport sediment; $\mathrm{p}<0.001)$ as well as flow velocity $(\mathrm{p}<0.001)$

(Naden et al. 2016). Interplay between fine sediment supply, stream flows and aquatic and riparian vegetation is the key to understanding how the channel system has evolved over time and will respond to future land management and climate change (Grabowski and Gurnell 2016).

\section{Research needs in sloping farmland-dominated catchments}

A hierarchical framework, as given in Fig. 1, can be employed to investigate fine sediment sources across multiple scales; four elements are highlighted: (1) identifying catchment-scale spatial distribution of fine sediment sources and temporal changes in sediment production, (2) measuring features (e.g., riparian vegetation, wetlands, dams and hydrologic connections) along the channel system that could intercept fine sediment; (3) determining fine sediment delivery capacity of the river at the segment scale; and (4) quantifying spatial and temporal (seasonal and inter-annual) changes of channel dimensions and fine sediment characteristics at the reach scale. Future work could consider the following aspects.

\section{Combined use of multiple composite fingerprints}

It is well accepted to use an optimum composite fingerprint comprising a minimum number of tracers in sediment source apportioning (Zhang and Liu 2016). Nevertheless, Sherriff et al. (2015) reported that uncertainty in predictions of source contributions became smaller if more tracers were used. This inconsistency needs further investigation through more case studies. It was recently noted 
602

603

604

605

606

607

608

609

610

611

612

613

614

615

616

617

618

619

620

621

622

623

that the link between a tracer's ability to discriminate among sources and its reliability in estimating source contributions have received less scrutiny and may be weak (Zhang and Liu 2016). Multiple composite fingerprints (i.e., different sets of tracers) can be used in parallel to improve the accuracy and reliability of the contribution estimates. Mean contributions averaged over multiple composite fingerprints may be more reliable and closer to the population means than estimates derived using a single composite fingerprint alone and may provide greater certainty of contribution estimates.

Therefore, a minimum number of potential sediment sources and a maximum number of composite fingerprints, each with a minimum number of tracers, are recommended (Zhang and Liu, 2016). In addition to the widely used statistical approach, prior knowledge of biogeochemical, hydrological, soil erosion and environmental processes and related parameters should be considered in tracer selection.

Temporal and spatial variation of fine sediment sources and delivery

Sediment sources are commonly defined either spatially (e.g., reach sub-catchments and geological sub-areas) or typologically (e.g., land-use types, surface vs subsurface sources) (Collins and Walling 2002). Land-use time series maps and agricultural census records are useful to identify temporal changes in intensive crop cultivation and livestock farming in source uplands. Rainfall regime governs temporal variability of soil erosion and sediment production. Agriculture could be the dominant contributor to suspended sediment during cropping season while river banks could be an important source of suspended sediment during winter (particularly snowmelt) months (Lamba et al. 2015b). In channels, the bed downcuts slowly during moderate- and low-flow hydrologic events. 
624

625

626

627

628

629

630

631

632

633

634

635

636

637

638

639

640

641

642

643

644

645

Deposition and replenishment of sediment to the bed is pronounced as a result of very high-flow hydrologic events (Fox et al. 2010). The channel bed in a lowland catchment functions as a temporary storage zone of fine sediment. The effect of temporary fine sediment storage (known as 'memory effect') may alter the representativeness of fine sediment collected downstream for source apportionment, particularly in large braided river catchments (Navratil et al. 2010; Evrard et al. 2011). Transport of suspended fine sediment during storm events and resuspension of bed fine sediment are different from baseflow periods. Improved understanding of seasonal and inter-annual variability of fine sediment production and delivery is essential for identification of the geomorphological impacts of excess fine sediment within river systems. Based on identification of fine sediment sources by multiple-tracer approaches, mapping of delivery pathways and measurement of fine sediment fluxes, a complete, spatially distributed sediment balance from source uplands to catchment outlet should be made at the catchment scale, and temporal dynamics of sediment delivery, to and within, the channel system quantified as a function of landscape position or hydrologic connection (Koiter et al. 2013b). Reliable identification of critical fine sediment source types and erosion hotspots is essential for optimizing fine sediment management and informing best soil conservation practices at the catchment scale. Combined use of soil erosion and sediment transport models, such as the Revised Universal Soil Loss Equation 2 (RUSLE 2) (USDAARS 2006) and Water Erosion Prediction Project (WEPP) model (Flanagan and Livingston 1995), with sediment source tracking techniques with selected tracers (Lamba et al. 2015b) and temporal markers could be an effective approach toward this end. 
647 Multivariate mixing models provide relative contribution estimates of fine sediment sources

648 (Collins et al. 1997a,b; Franks and Rowan 2000). In addition to particle size, organic matter

649 correction factors and other weighing factors, a temporal dimension should be incorporated to

650 represent the changes in fine sediment source over time (Walling, 2013a,b). Additional uncertainties

651 associated with non-linear additivity need also to be considered in modeling (Lees 1997; Small et

652 al 2004). Few attempts have yet been made to develop precise guidelines for selecting appropriate

653 tracer properties to be incorporated into the mixing model (Davis and Fox 2009).

654

655

656

657

658

659

660

661

662

663

664

665

666

667

Effect of construction activities and road verges

Fine sediment deliveries per unit area via runoff from construction sites and damaged road verges are usually much greater than those from agricultural lands (Owens et al. 2000; Collins et al. 2010a).

Fine sediment from construction sites can be a significant contributor of sediment flux to channel systems if erosion controls are not implemented. The magnitude of fine sediment transport from the site is governed by soil type, site slope, erosion control practices and rainfall characteristics. In particular, rainfall intensity plays a much more important role in fine sediment transport than the

"first flush" generated by the first rainfall (Owens et al. 2000). Additionally, attention should be given to the potential for fine sediment transport resulting from intensive human disturbances in hilly areas.

Development of an environmental forensics tool 
669 Sediment fingerprinting offers a potentially valuable tool for accurate assessment of fine sediment

670 sources, in support of the development efficient mitigation strategies for excess fine sediment

671 loading and resultant environmental problems in a catchment (Davis and Fox 2009). Nevertheless,

672 it has rarely been practiced as a catchment management tool for fine sediment within a regulatory

673 framework. Regarding the multidisciplinary nature, forensic-style investigations of sediment

674 sources should use robust quantitative schemes incorporating various data and modeling

675 uncertainties and be practically resourced to achieve adequate accuracy and precision (Rowan et al.

676 2012; Small et al. 2004). When compared with the current source assessment tools in developing

677 total maximum daily load standards (TMDLs) for sediment (USEPA, 1999), sediment fingerprinting

678 offers significant improvement regarding source type and spatial location. A conceptual framework

679 for applying sediment source fingerprinting along with sediment budgeting and modeling in a

680 regulatory framework was proposed for developing justifiable sediment TMDLs, with special

681 reference to the U.S. TMDL program (Mukundan et al. 2012).

682

683

684

685

686

687

Practices for fine sediment control

Lower surface hydrological connectivity in well-drained catchments as a result of a dominant role of subsurface flows can cause decrease in sediment transport (Sherriff et al. 2016). Management of hydrological connectivity becomes an effective approach to preventing long distance transport of fine sediment and associated pollutants. Temporary measures such as sediment fences in fields subject to high soil erosion risk may be taken prior to the occurrence of extreme rainfall events 
690

691

692

694

695

696

697

698

699

700

701

702

703

704

705

706

707

(Vinten et al. 2014). To minimize river bank erosion, limiting livestock (cattle, ducks etc) access to rivers and river bank stabilization are recommended (Lamba et al. 2015a). Other engineering practices for sediment control include stormwater detention facilities (e.g., small dams and pools), riparian buffers, wetlands and targeted in-channel management (e.g., installation of various sediment traps) (Mukundan et al. 2012; Lamba et al. 2015a). Tiessen et al. (2011) reported that small dams in an agricultural river basin could reduce the annual sediment load by $70 \%$. Riparian buffer zones and wetlands could slow the stream flow, resulting in the deposition of fine sediment, and the trapping efficiency was largely dependent on the vegetational and geomorphical conditions of these features. Constructed and restored wetlands receiving agricultural runoff could achieve sediment removal efficiencies greater than 50\% (O'Geen et al. 2010). However, relatively few data of particle size distribution and organic matter content have been reported for suspended sediment leaving dams or wetlands although fine sediment would be expected to be preferentially exported from these features. Cost-effective catchment-wide practices for reducing sediment control are increasingly needed with respect to diffuse fine sediment sources.

Sediment source tracking at multiple scales within a catchment can support the formulation and continued optimization of fine sediment control and management strategies. A general procedure for this purpose, which is modified from the procedure described by Madej (2007), may include the following seven steps: 1) define the critical problems relating to soil erosion and fine sediment transport; 2) acquire regional background information by reviewing various available sources of literature; 3) subdivide the concerned catchment into sub-catchments or terrain units with respect to land uses, vegetation and spatial patterns of hydrological processes, soil erosion and sediment transport; 4) identify the locations and timing of hillslope sediment sources, channel bank erosion 
712

713

714

and channel incision using suitable erosion models and/or monitoring data; 5) assess fine sediment delivery and apportioning its sources using optimum composite fingerprint(s); 6) prioritize, prescribe and implement measures for fine sediment control; 7) and monitor the effectiveness of the fine sediment control practice implemented using source tracking techniques in order to prescribe and take more effective management actions.

\section{Conclusions}

A reliable identification of contributing sources and delivery pathways of fine sediment into riverine systems is of pivotal importance for sustainable catchment management. Accurate provenance of fine sediment is still limited by: problems associated with representativeness of sediment and source soil samples; the complexity and stochasticity of transport processes; uncertainties associated with source tracking approaches, and; lack of temporally and spatially distributed monitoring data for fine sediment production and delivery. This review provides an overview of conservative tracking and source apportionment modeling techniques to pinpoint fine sediment to individual sloping fields and non-field areas according to their fingerprints. These fingerprints may comprise: selected fallout radionuclides; geochemical properties; mineral magnetics; elemental composition; fluorescence of organic matter; anthropogenic pollutants; stable isotopes; physical properties, or; other tracers. Despite varying forms of erosion processes and particle size selectivity, mobilized fine sediment can maintain the same fingerprint as the original sources or secondary sources (e.g., those resuspended during rain events). The multiple tracer approach along with numerical mixing models could provide a valuable forensic technique to resolve a legal dispute between land users and 
catchment managers regarding environmental pollution issues relating to fine sediment transport, and could be useful in developing total maximum daily load for fine sediment. The quantitative relationships between tracers and particle size composition and organic matter content are likely to vary between tracers and the use of a single correction factor for all tracers may not be appropriate. Through combined use of multiple-tracer approach and seasonal and rain event based monitoring of suspended and deposited fine sediment and channel geomorphological properties at nested sites within a catchment, spatial distribution of fine sediment sources and temporal changes of their contributions at a specific location can be identified. Such information will be essential for prioritizing the implementation of erosion control measures to reduce the loading of fine sediment and associated contaminants to surface water bodies, particularly for agriculture-dominated catchments, catchments known to have high agrochemical or contaminants loadings and catchments with complex and changing land-use. However, this integrated scheme is demanding in terms of resources (i.e., time, funding and personnel), and this represents an important constraint on wider application.

\section{Acknowledgments}

This work was supported by the GAIA Surface Soil Resource Inventory and Integration (SSORii)

Project of MOE, Kangwon National University Research Grant (2013: C1009703-01-01), Japan Society for the Promotion of Science (RONPAKU Program, ID No. CAS-11313), National Natural Science Foundation of China (Nos. 21307152 and 41471268) and CAS President's International Fellowship Initiative Fellowship (No. 2016VEA040). 


\section{References}

Alewell, C., Meusburger, K., Brodbeck, M., \& Banninger, D. (2008). Methods to describe and predict soil erosion in mountain regions. Landscape and Urban Planning, 88, 46-53.

Balesdent, J., Wagner, G. H., \& Mariotti, A. (1988). Soil organic matter turnover in long-term field experiments as revealed by carbon-13 natural abundance. Soil Science Society of America Journal, 52, 118-124.

Barthod, L. R. M., Liu, K., Lobb, D. A., Owens, P. N., Martínez-Carreras, N., Koiter, A. J., et al. (2015). Selecting color-based tracers and classifying sediment sources in the assessment of sediment dynamics using sediment source fingerprinting. Journal of Environmental Quality, $44,1605-1616$.

Bartley, R., Hawdon, A., Post, D. A., \& Roth, C. H. (2007). A sediment budget for a grazed semiarid catchment in the Burdekin basin, Australia. Geomorphology, 87, 302-321.

Bhattarai, R., \& Dutta, D. (2007). Estimation of soil erosion and sediment yield using GIS at catchment scale. Water Resources Management, 21, 1635-1647.

Blake, W. H., Ficken, K. J., Taylor, P., Russell, M. A., \& Walling, D. E. (2012). Tracing crop-specific sediment sources in agricultural catchments. Geomorphology, 139-140, 322-329.

Blessing, M., Jochmann, M. A., \& Schmidt, T. C. (2007). Pitfalls in compound-specific isotope analysis of environmental samples. Analytical and Bioanalytical Chemistry, doi:10.1007/s00216-007-1588-1.

Bo, T., Fenoglio, S., Malacarne, G., Pessino, M., \& Sgariboldi, F. (2007). Effects of clogging on stream macroinvertebrates: an experimental approach. Limnologica - Ecology and Management of Inland Waters, 37, 186-192. 
Böke, H., Akkurt, S., Özdemir, S., Göktürk, E. H., \& Caner Saltik, E. N. (2004). Quantification of $\mathrm{CaCO}_{3}-\mathrm{CaSO}_{3} \cdot 0.5 \mathrm{H}_{2} \mathrm{O}-\mathrm{CaSO}_{4} \cdot 2 \mathrm{H}_{2} \mathrm{O}$ mixtures by FTIR analysis and its ANN model. Materials Letters, 58, 723-726.

Boonyatumanond, R., Wattayakorn, G., Amano, A., Inouchi, Y., \& Takada, H. (2007). Reconstruction of pollution history of organic contaminants in the upper Gulf of Thailand by using sediment cores: First report from Tropical Asia Core (TACO) project. Marine Pollution Bulletin, 54, 554-565.

Bravo-Espinoza, M., Mendoza, M. E., Medina-Orozco, L., Prat, C., Garcia-Oliva, F., \& LopezGranados, E. (2009). Runoff, soil loss and nutrient depletion under traditional and alternative cropping systems in the Transmexican volcanic belt, Central Mexico. Land Degradation \& Development, 20, 640-653.

Brown, A. G. (1985). The potential use of pollen in the identification of suspended sediment sources. Earth Surface Processes and Landforms, 10, 27-32.

Brown, R. B., Cutshall, N. H., \& Kling, G. F. (1981a). Agricultural erosion indicated by Cs-137 redistribution 1. Levels and distribution of Cs-137 activity in soils. Soil Science Society of America Journal, 45: 1184-1190.

Brown, R. B., Kling, G. F., \& Cutshall, N. H. (1981b). Agricultural erosion indicated by Cs-137 redistribution 2. Estimates of erosion rates. Soil Science Society of America Journal, 45, 11911197.

Busacca, A. J., Cook, C. A., \& Mulla, D. J. (1993). Comparing landscape-scale estimation of soil erosion in the Palouse using Cs-137 and RUSLE. Journal of Soil and Water Conservation, 48, $361-367$. 
Caitcheon, G. G., Olley, J. M., Pantus, F., Hancock, G., \& Leslie, C. (2012). The dominant erosion processes supplying fine sediment to three major rivers in tropical Australia, the Daly (NT), Mitchell (Qld) and Flinders (Qld) Rivers. Geomorphology, 151-152, 188-195.

Carter, J., Owens, P. N., Walling, D. E., \& Graham, J. L. L. (2003). Fingerprinting suspended sediment sources in a large urban river system. Science of the Total Environment, 314-316, $513-534$.

Chikaraishi, Y., \& Naraoka, H. (2003). Compound-specific $\delta$ D- $\delta^{13} \mathrm{C}$ analyses of $n$-alkanes extracted from terrestrial and aquatic plants. Phytochemistry, 63, 361-371.

Chillrud, S. N., Hemming, S., Shuster, E. L., Simpson, H. J., Bopp, R. F., Ross, J. M., et al. (2003). Stable lead isotopes, contaminant metals and radionuclides in upper Hudson River sediment cores: implications for improved time stratigraphy and transport processes. Chemical Geology, $199,53-70$.

Clement, B. M., Javier, J., Say, J. P., \& Ross, M. S. (2011). The effects of wildfires on the magnetic properties of soils in the Everglades. Earth Surface Processes and Landforms, 36, 460-466.

Collins, A. L., \& Walling, D. E. (2002). Selecting fingerprint properties for discriminating potential suspended sediment sources in river basins. Journal of Hydrology, 261, 218-244.

Collins, A. L., \& Walling, D. E. (2007). Sources of fine sediment recovered from the channel bed of lowland groundwater-fed catchments in the UK. Geomorphology, 88, 120-138.

Collins, A. L., Walling, D. E., \& Leeks, G. J. L. (1997a). Source type ascription for fluvial suspended sediment based on a quantitative composite fingerprinting technique. Catena, 29, 1-27.

Collins, A. L., Walling, D. E., \& Leeks, G. J. L. (1997b). Use of the geochemical record preserved in floodplain deposits to reconstruct recent changes in river basin sediment sources. 
823 Collins, A. L., Walling, D. E., Stroud, R. W., Robson, M., \& Peet, L. M. (2010a). Assessing damaged road verges as a suspended sediment source in the Hampshire Avon catchment, southern United Kingdom. Hydrological Processes, 24, 1106-1122.

826

Collins, A. L., Walling, D. E., Webb, L., \& King, P. (2010b). Apportioning catchment scale sediment sources using a modified composite fingerprinting technique incorporating property weightings and prior information. Geoderma, 155, 249-261.

Collins, A. L., Walling. D. E., \& Leeks. G. J. L. (1998). Use of composite fingerprints to determine the provenance of the contemporary suspended sediment load transported by rivers. Earth Surface Processes and Landforms, 23, 31-52.

Collins, A. L., Zhang, Y., McChesney, D., Walling, D. E., Haley, S., \& Smith, P. (2012). Sediment source tracing in a lowland agricultural catchment in southern England using a modified procedure combining statistical analysis and numerical modelling. Science of the Total Environment, 414, 301-317.

D’Haen, K., Verstraeten, G., \& Degryse, P. (2012). Fingerprinting historic fluvial sediment fluxes. Progress in Physical Geography, 36, 154-186.

Davis, C. M., \& Fox, J. F. (2009). Sediment fingerprinting: review of the method and future improvements for allocating nonpoint source pollution. Journal of Environmental Engineering, $135,490-504$.

Deasy. C., \& Quinton, J. N. (2010). Use of rare earth oxides as tracers to identify sediment source areas for agricultural hillslopes. Solid Earth, 1, 111-118. 
843

844

845

846

847

848

849

850

851

852

853

854

855

856

857

858

859

860

861

862

863

864

Dutton, R., Anisfeld, A. C., \& Ernstberger, H. (2013). A novel sediment fingerprinting method using filtration: Application to the Mara River, East Africa. Journal of Soils and Sediments, 13, $1708-1723$.

Dyer, F. J. \& Olley, J. M. (1996). Preliminary results from determining sediment sources to the Tarago Reservoir, Victoria, Australia: implications for sediment yield. In Erosion and Sediment Yield: Global and Regional Perspectives (pp. 143-151) (Proceedings of the Exeter Symposium), Wallingford.

Elliott, G., Campbell, B., \& Loughran, R. (1990). Correlation of erosion measurements and soil caesium-137 content. The International Journal of Applied Radiation and Isotopes, 41, 713717.

Evrard, O., Navratil, O., Ayrault, S., Ahmadi, M., Némery, J., Legout, C., et al. (2011). Combining suspended sediment monitoring and fingerprinting to determine the spatial origin of fine sediment in a mountainous river catchment. Earth Surface Processes and Landforms, 36, 1072-1089.

Phillips, J. M., Russell, M. A., \& Walling, D. E. (2000). Time-integrated sampling of fluvial suspended sediment: A simple methodology for small watersheds. Hydrological Processes, 14, $2589-2602$.

Flanagan, D. C., \& Livingston, S. J. (1995). WEPP user summary. NSERL Report No. 11. USDAARS National Soil Erosion Research Laboratory, W. Lafayette, Ind.

Foster, I. D., Boardman, J., \& Keay-Bright, J. (2007). Sediment tracing and environmental history for two small catchments, Karoo Uplands, South Africa. Geomorphology, 90, 126-143.

Foucher, A. Laceby, P. J., Salvador-Blanes, S., Evrard, O., Le Gall, M., Lefèvre, I., et al. (2015). 

Quantifying the dominant sources of sediment in a drained lowland agricultural catchment: The application of a thorium-based particle size correction in sediment fingerprinting. Geomorphology, 250, 271-281.

Fox, J. F. (2005). Fingerprinting using biogeochemical tracers to investigate watershed processes. Ph.D. thesis, University of Iowa.

Fox, J. F., \& Papanicolaou, A. N. (2007). The use of carbon and nitrogen isotopes to study watershed erosion processes. Journal of the American Water Resources Association, 43, 1047-1064.

Fox, J. F., Davis, C. M., \& Martin, D. K. (2010). Sediment source assessment in a lowland watershed using nitrogen stable isotopes. Journal of the American Water Resources Association, 46, $1192-1204$.

Fox, J. F., \& Papanicolaou, A. N. (2008). An un-mixing model to study watershed erosion processes. Advances in Water Resources, 31, 96-108.

Fox, W. M., Johnson, M. S., Jones, S. R., Leah, R. T., \& Copplestone, D. (1999). The use of sediment cores from stable and developing salt marshes to reconstruct historical contamination profiles in the Mersey Estuary, UK. Marine Environmental Research, 47, 311-329.

Franks, S. W., \& Rowan, J. S. (2000). Multi-parameter fingerprinting of sediment sources: uncertainty estimation and tracer selection. In L. R. Bentley, C. A. Brebbia, W. G. Gray, G. F. Pinder, \& J. F. Sykes (Eds.), Computational Methods in Water Resources (pp. 1067-1074). Rotterdam: Balkema.

Franz, C., Makeschin, F., Weiß, H., \& Lorz, C. (2013). Geochemical signature and properties of sediment sources and alluvial sediments within the Lago Paranoá catchment, Brasilia DF: A 

study on anthropogenic introduced chemical elements in an urban river basin. Science of the Total Environment, 452-453, 411-420.

Frostick, L. E., Lucas, P. M., \& Reid, I. (1984). The infiltration of fine matrices into coarse-grained alluvial sediments and its implications for stratigraphic interpretation. Journal of the Geological Society of London, 141, 955-965.

Ganasri, B. P., \& Ramesh, H. (2016). Assessment of soil erosion by RUSLE model using remote sensing and GIS - A case study of Nethravathi Basin. Geoscience Frontiers, 7, 953-961.

Gao, B., Liu, Y., Sun, K., Liang, X. R., Peng, P., Sheng, G., \& Fu, J. (2008). Precise determination of cadmium and lead isotopic compositions in river sediments. Analytica Chimica Acta, 612, $114-120$.

Gibbs, M. (2008). Identifying source soils in contemporary estuarine sediments: A new compoundspecific isotope method. Estuaries and Coasts, 31, 344-359.

Gibbs, M. (2014). Protocols on the use of the CSSI Technique to identify and apportion soil sources from land use. NIWA Client Report HAM2013-106 prepared for Joint FAO/IAEA Division of Nuclear Techniques in Food and Agriculture (Coordinated Research Project number D1.20.11).

Grabowski, R. C., \& Gurnell, A. M. (2016). Diagnosing problems of fine sediment delivery and transfer in a lowland catchment. Aquatic Sciences, 78, 95-106.

Greenwood, P. (2012). Tracing fine-sediment using artificial radionuclides. In L. Clarke (Ed.), Geomorphological Techniques (on-line edition) Chapter 3; Section 5.2 (pp. 1-10). London: British Society for Geomorphology.

Grimes, C. B., John, B. E., Kelermen, P. B., Mazdab, F. K., Wooden, J. L., Cheadle, M. J., et al. (2007). Trace element chemistry of zircons from oceanic crust: a method for distinguishing 
detrital zircon provenance. Geology, 35, 643-646.

Grimshaw, D. L., \& Lewin, J. (1980). Source identification for suspended sediments. Journal of Hydrology, 47, 151-162.

Guzmán, G., Quinton, J. N., Nearing, M. A., Mabit, L., \& Gómez, J. A. (2013). Sediment tracers in water erosion studies: current approaches and challenges. Journal of Soils and Sediments, 13, 816-833.

Haddadchi, A., Olley, J., \& Laceby, P. (2014). Accuracy of mixing models in predicting sediment source contributions. Science of the Total Environment, 497-498, 139-152.

Haddadchi, A., Ryder, D. S., Evrard, O., \& Olley, J. (2013). Sediment fingerprinting in fluvial systems: review of tracers, sediment sources and mixing models. International Journal of Sediment Research, 28, 560-578.

Hancock, G. J., Wilkinson, S. N., Hawdon, A. A., \& Keen, R. J. (2014). Use of fallout tracers ${ }^{7}$ Be, ${ }^{210} \mathrm{~Pb}$ and ${ }^{137} \mathrm{Cs}$ to distinguish the form of sub-surface soil erosion delivering sediment to rivers in large catchments. Hydrological Processes, 28, 3855-3874.

Hartmann, P. C., Quinn, J. G., Cairns, R. W., \& King, J. W. (2005). Depositional history of organic contaminants in Narragansett Bay, Rhode Island, USA. Marine Pollution Bulletin, 50, 388-395.

Harvey, J. W., Drummond, J. D., Martin, R. L., McPhillips, L. E., Packman, A. I., Jerolmack, D. J., et al. (2012). Hydrogeomorphology of the hyporheic zone: Stream solute and fine particle interactions with a dynamic streambed. Journal of Geophysical Research, 117, G00N11, doi:10.1029/2012JG002043.

Hasholt, B., Walling, D. E., \& Owens, P. N. (2000). Sedimentation in arctic proglacial lakes: Mittivakkat Glacier, south-east Greenland. Hydrological Processes, 14, 679-699. 
He, Q., \& Walling, D. (1996). Use of fallout $\mathrm{Pb}-210$ measurements to investigate longer-term rates and patterns of overbank sediment deposition on the floodplains of lowland rivers. Earth Surface Processes and Landforms, 21, 141-154.

Helm, P. A., Milne, J., Hiriart-Baer, V., Crozier, P., Kolic, T., Lega, R., et al. (2011). Lake-wide distribution and depositional history of current- and past-use persistent organic pollutants in Lake Simcoe, Ontario, Canada. Journal of Great Lakes Research, 37, 132-141.

Hobo, N., Makaske, B., Middelkoop, H., \& Wallinga, J. (2010). Reconstruction of floodplain sedimentation rates: a combination of methods to optimize estimates. Earth Surface Processes and Landforms, 35, 1499-1515.

Hom, W., Risebrou, R. W., Soutar, A., Young, D. R. (1974). Deposition of DDE and polychlorinated biphenyls in dated sediments of Santa Barbara Basin. Science, 184: 1197-1199.

Horowitz, A. (1991). A primer on sediment-trace element chemistry, $2^{\text {nd }}$ edition. Open-File Report 91-76, United States Geological Survey.

Horowitz, A. J., Stephens, V. C., Elrick, K. A., \& Smith, J. A. (2012). Annual fluxes of sedimentassociated trace/major element geochemistry of Lake Coeur d'Alene, Idaho, USA. Part II: subsurface sediments. Hydrological Processes, 9, 35-54.

Hughes, A. O., Olley, J. M., Croke, J. C., \& McKergow, L. A. (2009). Sediment source changes over the last 250 years in a dry-tropical catchment, central Queensland, Australia. Geomorphology, 104, 262-275.

Jones, C. S., \& Schilling, K. E. (2011). Agricultural intensification to conservation: sediment transport in the Raccoon River, Iowa, 1916-2009. Journal of Environmental Quality, 40, 19111923. 
Kemp, P., Sear, D., Collins, A., Naden, P., \& Jones, I. (2011). The impacts of fine sediment on riverine fish. Hydrological Processes, 25, 1800-1821.

Kimoto, A., Nearing, M., Shipitalo, M. J., \& Polyakov, V. O. (2006). Multi-year tracking of sediment sources in a small agricultural watershed using rare earth elements. Earth Surface Processes and Landforms, 31, 1763-1774.

Koiter, A. J., Owens, P. N., Petticrew, E. L., \& Lobb, D. A. (2015). The role of gravel channel beds on the particle size and organic matter selectivity of transported fine-grained sediment: implications for sediment fingerprinting and biogeochemical flux research. Journal of Soils and Sediments, 15, 2174-2188.

Koiter, A. J., Lobb, D.A., Owens, P. N., Petticrew, E. L., Tiessen, K. H., \& Li, S. (2013a). Investigating the role of connectivity and scale in assessing the sources of sediment in an agricultural watershed in the Canadian prairies using sediment source fngerprinting. Journal of Soils and Sediments, 13, 1676-1691.

Koiter, A.J., Owens, P. N., Petticrew, E. L., \& Lobb, D. A. (2013b). The behavioural characteristics of sediment properties and their implications for sediment fingerprinting as an approach for identifying sediment sources in river basins. Earth-Science Reviews, 125, 24-42.

Krause, A. K., Franks, S. W., Kalma, J. D., Loughran, R. J., \& Rowan, J. S. (2003). Multi-parameter fingerprinting of sediment deposition in a small gullied catchment in SE Australia. Catena, 53, $327-348$.

Krein, A., Petticrew, E., \& Udelhoven, T. (2003). The use of fine sediment fractal dimensions and colour to determine sediment sources in a small watershed. Catena, 53, 165-179.

Lamba, J. Thompson, A. M., Karthikeyan, K. G., \& Fitzpatrick, F. A. (2015a). Sources of fine 
sediment stored in agricultural lowland streams, Midwest, USA. Geomorphology 236, 44-53.

Lamba, J., Karthikeyan, K. G., \& Thompson, A. M. (2015b). Apportionment of suspended sediment sources in an agricultural watershed using sediment fingerprinting. Geoderma, 239-240, 2533.

Lambert, C. P., \& Walling, D. E. (1988). Measurement of channel storage of suspended sediment in a gravel-bed river. Catena, 15, 65-80.

Land, M., Ohlander, B., Ingri, J., \& Thunberg, J. (1999). Solid speciation and fractionation of rare earth elements in a spodosol profile from northern Sweden as revealed by sequential extraction. Chemical Geology, 160, 121-138.

Larsen, L., Harvey, J., Skalak, K., \& Goodman, M. (2015). Fluorescence-based source tracking of organic sediment in restored and unrestored urban streams. Limnology and Oceanography, 60, 1439-1461.

Latimer, J. S., \& Quinn, J. G. (1996). Historical trends and current inputs of hydrophobic organic compounds in an urban estuary: The sedimentary record. Environmental Science \& Technology, $30,623-633$.

Lees, J. A. (1997). Mineral magnetic properties of mixtures of environmental and synthetic materials: linear additivity and interaction effects. Geophysical Journal International, 131, $335-346$.

Loisel, H., Mangin, A., Vantrepotte, V., Dessailly, D., Dinh, D. N., Garnesson, P., et al. (2014). Variability of suspended particulate matter concentration in coastal waters under the Mekong's influence from ocean color (MERIS) remote sensing over the last decade. Remote Sensing of Environment, 150, 218-230. 
Longworth, G., Becker, L. W., Thompson, R., Oldfield, F., Dearing, J. A., \& Rummery, T. A. (1979). Mossbauer and magnetic studies of secondary iron oxides in soil. Journal of Soil Science, 30, 93-110.

Mabit, L., Benmansour, M., \& Walling, D. (2008). Comparative advantages and limitations of the fallout radionuclides ${ }^{137} \mathrm{Cs},{ }^{210} \mathrm{~Pb}$ ex and ${ }^{7} \mathrm{Be}$ for assessing soil erosion and sedimentation. Journal of Environmental Radioactivity, 99, 1799-1807.

Mabit, L., Bernard, C., \& Laverdiére, M. (2002). Quantification of soil redistribution and sediment budget in a Canadian watershed from fallout caesium-137 $\left({ }^{137} \mathrm{Cs}\right)$ data. Canadian Journal of Soil Science, 82, 423-431

Madej, M. A. (2007). A strategy to reduce fine sediment from tributaries in the Trinity River Basin. A report in fulfillment of the Trinity River Restoration Project Agreement \# 04AA202062. U.S. Geological Survey Western Ecological Research Center Redwood Field Station. Arcata, CA.

Martínez-Carreras, N., Udelhoven, T., Krein, A., Gallart, F., Iffly, J. F., Ziebel, J., et al. (2010). The use of sediment colour measured by diffuse reflectance spectrometry to determine sediment sources: Application to the Attert River catchment (Luxembourg). Journal of Hydrology, 382, 49-63.

Matsumoto, K., Kawamura, K., Uchida, M., \& Shibata, Y. (2007). Radiocarbon content and stable carbon isotopic ratios of individual fatty acids in subsurface soil: Implication for selective microbial degradation and modification of soil organic matter. Geochemical Journal, 41, 483492.

Middelkoop, H. (2002). Reconstructing floodplain sedimentation rates from heavy metal profiles by inverse modelling. Hydrological Processes, 16, 47-64. 
1018

1019

1020

1021

1022

1023

1024

1025

1026

1027

1028

1029

1030

1031

1032

1033

1034

1035

1036

1037

1038

1039

Mil-Homens, M., Blum, J., Canário, J., Caetano, M., Costa, A. M., Lebreiro, S. M., et al. (2013). Tracing anthropogenic $\mathrm{Hg}$ and $\mathrm{Pb}$ input using stable $\mathrm{Hg}$ and $\mathrm{Pb}$ isotope ratios in sediments of the central Portuguese Margin. Chemical Geology, 336, 62-71.

Mukundan, R., Radcliffe, D. E., Ritchie, J. C., Risse, L. M., \& Mckinley, R. (2010). Sediment fingerprinting to determine the source of suspended sediment in a southern Piedmont stream. Journal of Environmental Quality, 39, 1328-1337.

Mukundan, R., Walling, D. E., Gellis, A. C., Slattery, M. C., \& Radcliffe, D. E. (2012). Sediment source fingerprinting: Transforming from a research tool to a management tool. Journal of the American Water Resources Association, 48, 1241-1257.

Naden, P. S., Murphy, J. F., Old, G. H., Newman, J., Scarlett, P., Harman, M., et al. (2016). Understanding the controls on deposited fine sediment in the streams of agricultural catchments. Science of the Total Environment, 547, 366-381.

Nagle, G. N., Lassoie, J. P., Fahey, T. J., \& McIntyre, S. C. (2000). The use of caesium-137 to estimate agricultural erosion on steep slopes in a tropical watershed. Hydrological Processes, $14,957-969$.

Navratil, O., Legout, C., Gateuille, D., Esteves, M., \& Liebault, F. (2010). Assessment of intermediate fine sediment storage in a braided river reach (Southern French Prealps). Hydrological Processes, 4, 1318-1332.

Newbold, J. D., Thomas, S. A., Minshall, G. W., Cushing, C. E., \& Georgian, T. (2005). Deposition, benthic residence, and resuspension of fine organic particles in a mountain stream. Limnology and Oceanography, 50, 1571-1580.

Nicholls, D. J. (2001). The source and behaviour of fine sediment deposits in the River Torridge 
1041

Olley, J. M., \& Caitcheon, G. (2000). Major element chemistry of sediments from the DarlingBarwon river and its tributaries: implications for sediment and phosphorus sources. Hydrological Processes, 14, 1159-1175.

Olley, J., Burton, J., Smolders, K., Pantus, F., \& Pietsch, T. (2013). The application of fallout radionuclides to determine the dominant erosion process in water supply catchments of subtropical South-east Queensland, Australia. Hydrological Processes, 27, 885-895.

Owens, D. W., Jopke, P., Hall, D. W., Balousek, J., \& Roa, A. (2000). Soil erosion from two small construction sites, Dane County, Wisconsin. Fact Sheet FS-109-00, United States Geological Survey.

Owens, P. N., Blake, W. H., Giles, T. R., \& Williams, N. D. (2012). Determining the effects of wildfire on sediment sources using ${ }^{137} \mathrm{Cs}$ and unsupported ${ }^{210} \mathrm{~Pb}$ : the role of natural landscape disturbances and driving forces. Journal of Soils and Sediments, 12, 982-994.

Palmer, M. A., Covich, A. P., Lake, S., Biro, P., Brooks, J. J., Cole, J., et al. (2000). Linkages between aquatic sediment biota and life above sediments as potential drivers of biodiversity and ecological processes: A disruption or intensification of the direct and indirect chemical, physical, or biological interactions between aquatic sediment biota and biota living above the sediments may accelerate biodiversity loss and contribute to the degradation of aquatic and riparian habitats. BioScience, 50, 1062-1075.

Papanicolaou, A. N., Fox, J. F., \& Marshall, J. (2003). Soil fingerprinting in the Palouse Basin, USA, using stable carbon and nitrogen isotopes, International Journal of Sediment Research, 18, $278-284$. 
1062

1063

1064

1065

1066

1067

1068

1069

1070

1071

1072

1073

1074

1075

1076

1077

1078

1079

1080

1081

1082

1083

Parnell, A. C., Inger, R., Bearhop, S., \& Jackson, A. L. (2010). Source partitioning using stable isotopes: coping with too much variation. PloS ONE, 5, e9672.

Peart, M. R., \& Walling, D. E. (1986). Fingerprinting sediment source: the example of a drainage basin in Devon, UK. In D. B. S. Delivery, D. E. Walling, \& M. P. Bordas (Eds.) IAHS Publication No. 159. (pp. 41-55). Wallingford: IAHS Press.

Petit, J. C. J., DeJong, J., Chou, L., \& Mattielli, N. (2008). Development of Cu and Zn isotope MCICPMS measurements: application to suspended particulate matter and sediments from the Scheldt Estuary. Geostandards and Geoanalytical Research, 32, 149-166.

Philips, J. M., Russell, M. A., \& Walling, D. E. (2000). Time-integrated sampling of fluvial suspended sediment: a simple methodology for small catchments. Hydrological Processes, 14, $2589-2602$.

Phillips, D., \& Gregg, J. (2003). Source partitioning using stable isotopes: coping with too many sources. Oecologia, 136, 261-269.

Polyakov, V. O., Nearing, M. A., \& Shipitalo, M. J. (2004). Tracking sediment redistribution in a small watershed: Implications for agro-landscape evolution. Earth Surface Processes and Landforms, 29, 1275-1291.

Poulenard, J., Legout, C., Némery, J., Bramorski, J., Navratil, O., Douchin, A., et al. (2012). Tracing sediment sources during floods using Diffuse Reflectance Infrared Fourier Transform Spectrometry (DRIFTS): A case study in a highly erosive mountainous catchment (Southern French Alps). Journal of Hydrology, 414-415, 452-462.

Poulenard, J., Perrette, Y., Fanget, F., Quetin, P., Trevisan, D., \& Dorioz, J. M. (2009). Infrared spectroscopy tracing of sediment sources in a small rural watershed (French Alps). Science of 
the Total Environment, 407, 2808-2819.

1085

1086

1087

1088

1089

1090

1091

1092

1093

1094

1095

1096

1097

1098

1099

Pulley, S., \& Rowntree, K. (2016a). Stages in the life of a magnetic grain: Sediment source discrimination, particle size effects and spatial variability in the South African Karoo. Geoderma, 271, 134-143.

Pulley, S., \& Rowntree, K. (2016b). The use of an ordinary colour scanner to fingerprint sediment sources in the South African Karoo. Journal of Environmental Management, 165, 253-262.

Qu, L. Q, (2014). Remote sensing suspended sediment concentration in the Yellow River. Ph.D. thesis, University of Connecticut.

Rehkämper, M., Wombacker, R., Horner, T. J., \& Xue, Z. (2011). Natural and anthropogenic Cd isotope variations. In M. Baskaran (Ed.), Handbook of environmental isotope geochemistry. Advances in Isotope Geochemistry (pp. 125-154). Berlin: Springer.

Rollinson, H. (1993). Using geochemical data: evaluation, presentation, interpretation. Harlow: Longman.

Rousseeuw, P., \& Croux, C. (1993). Alternatives to the median absolute deviation. Journal of the American Statistical Association, 88, 1273-1283.

Rowan, J. S., Black, S., \& Franks, S. W. (2012). Sediment fingerprinting as an environmental forensics tool explaining cyanobacteria blooms in lakes. Applied Geography, 32, 832-843.

Russell, M. A., Walling, D. E., \& Hodgkinson, R. A., (2001). Suspended sediment sources in two small lowland catchments in the UK. Journal of Hydrology, 252, 1-24.

Sergio, d. 1. S.-V., Claudio, B.-L., Roberto, M. d. A., Renan, C., Max, G., Andrew, S., et al. (2017). The CSSIAR v.1.00 Software: A new tool based on SIAR to assess soil redistribution using Compound Specific Stable Isotopes. SoftwareX, 6, 13-18. 
Shackle, V. J., Hughes, S., \& Lewis, V. T. (1999). The influence of three methods of gravel cleaning on brown trout, Salmo trutta, egg survival. Hydrological Processes, 13, 477-486.

Sherriff, S. C., Rowan, J. S., Fenton, O., Jordan, P., Melland, A. R., Mellander, P. E., et al. (2016). Storm event suspended sediment-discharge hysteresis and controls in agricultural watersheds: implications for watershed scale sediment management. Environmental Science \& Technology, $50,1769-1778$.

Sherriff, S. C., Franks, S. W., Rowan, J. S., Fenton, O., \& OhUallachain, D. (2015). Uncertaintybased assessment of tracer selection, tracer non-conservativeness and multiple solutions in sediment fingerprinting using synthetic and field data. Journal of Soils and Sediments, 15, $2101-2116$.

Shi, Z. L., Wen, A. B., Zhang, X. B., He, X. B., Li, H., \& Yan, D. C. (2012). ${ }^{137}$ Cs and ${ }^{210} \mathrm{~Pb}_{\mathrm{ex}}$ as soil erosion tracers in the hilly Sichuan Basin and the Three Gorges Area of China. Journal of Mountain Science, 9, $27-33$.

Small, I. F., Rowan, J. S., \& Franks, S. W. (2002). Quantitative sediment fingerprinting using a Bayesian uncertainty estimation framework, In F. J. Dyer, M. C. Thoms, \& J. M. Olley (Eds.), The Structure, Function and Management Implications of Fluvial Sedimentary Systems, IAHS Publication, No. 276 (pp. 443-450). Wallingford: IAHS Press.

Small, I. F., Rowan, J. S., Franks, S. W., Wyatt, A., \& Duck, R. W. (2004). Bayesian approach provides a robust tool for environmental forensic geoscience applications. In K. Pye \& D.J. Croft (Eds.), Forensic Geoscience: Principles, Techniques and Applications, Special Publications, vol. 232 (pp. 207-213). London: Geological Society.

Smith, H. G., \& Blake, W. H. (2014). Sediment fingerprinting in agricultural catchments: a critical 
Smith, H. G., Blake, W. H., \& Owens, P. N. (2013). Discriminating fine sediment sources and the application of sediment tracers in burned catchments: a review. Hydrological Processes, 27, 943-958

Takeda, A., Kimura, K., \& Yamasaki, S. (2004). Analysis of 57 elements in Japanese soils, with special reference to soil group and agricultural use. Geoderma, 119, 291-307. International Journal of Sediment Research, 9, 39-46. 

and quantity in the Canadian Prairies. Journal of Soil and Water Conservation, 66, 158-171.

1152

Toth, S. J., \& Alderfer, R. B. (1960). A procedure for tagging water stable soil aggregates with Co60. Soil Science, 89, 36-37.

Turnbull, L., Brazier, R. E., Wainwright, J., Dixon, L., \& Bol, R. (2008). Use of carbon isotope analysis to understand semi-arid erosion dynamics and long-term semi-arid land degradation. Rapid Communications in Mass Spectrometry, 22, 1697-1702.

United States Environmental Protection Agency (USEPA). (1999). Protocol for developing sediment TMDLs. EPA 841-B-99-004. Office of Water (4503F), United States Environmental Protection Agency, Washington D.C. 132 pp.

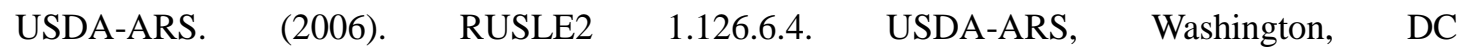
(http://fargo.nserl.purdue.edu/rusle2_dataweb/RUSLE2_Index.htm (accessed 27 June. 2014)). van der Waal, B., Rowntree, K., \& Pulley, S. (2015). Flood bench chronology and sediment source tracing in the upper Thina catchment, South Africa: the role of transformed landscape connectivity. Journal of Soils and Sediments, 15, 2398-2411.

Vinten, A. J. A., Loades, K., Addy, S., Richards, S., Stutter, M., Cook, Y., et al. (2014). Assessment of the use of sediment fences for control of erosion and sediment phosphorus loss after potato harvesting on sloping land. Science of the Total Environment, 468-469, 1234-1244.

Walden, J., Slattery, M. C., \& Burt, T. P. (1997). Use of mineral magnetic measurements to fingerprint suspended sediment sources: Approaches and techniques for data analysis. Journal of Hydrology, 202, 353-372.

Wallbrink, P. J., \& Murray, A. S. (1993). Use of fallout radionuclides as indicators of erosion 
1173

Wallbrink, P. J., Murray, A. S., \& Olley, J. M. (1999). Relating suspended sediment to its original depth using fallout radionuclides. Soil Science Society of America Journal, 63, 369-378.

Wallbrink, P. J., Murray, A. S., Olley, J. M., \& Olive, L. J. (1998). Determining sources and transit times of suspended sediment in the Murrumbidgee River, New South Wales, Australia, using fallout ${ }^{137} \mathrm{Cs}$ and ${ }^{210} \mathrm{~Pb}$. Water Resources Research, 34, 879-887.

Walling, D. E. (1983). The sediment delivery problem. Journal of Hydrology, 65, 209-237.

Walling, D. E. (2005). Tracing suspended sediment sources in catchments and river systems. Science of the Total Environment, 344, 159-184.

Walling, D. E. (2013a). Beryllium-7: the cinderella of fallout radionuclide sediment tracers? Hydrological Processes, 27, 830-844.

Walling, D. E. (2013b). The evolution of sediment source fingerprinting investigations in fluvial systems. Journal of Soils and Sediments, 13, 1658-1675.

Walling, D. E., \& Amos, C. M. (1999). Source, storage, and mobilisation of fine sediment in a chalk stream system. Hydrological Processes, 13, 323-340.

Walling, D. E., Collins, A. L., \& McMellin, G. K. (2003). A reconnaissance survey of the source of interstitial fine sediment recovered from salmonid spawning gravels in England and Wales. Hydrobiologia, 497, 91-108.

Walling, D. E., Owens, P. N., \& Leeks, G. J. L. (1999). Fingerprinting suspended sediment sources in the catchment of the River Ouse, Yorkshire, UK. Hydrological Processes, 13, 955-975.

Walser, C. A., \& Bart Jr., H. L. (2006). Influence of agriculture on in-stream habitat and fish community structure in Piedmont watersheds of the Chattahoochee River System. Ecology of 
1195

1196

1197

1198

1199

1200

1201

1202

1203

1204

1205

1206

1207

1208

1209

1210

1211

1212

1213

1214

1215

Warrick, J. A. (2013). Dispersal of fine sediment in nearshore coastal waters. Journal of Coastal Research, 29, 579-596.

Weiss, D. J., Rehkämper, M., Schoenberg, R., McLaughlin, M., Kirby, J., Campbell, P. G. C., et al. (2008). Application of nontraditional stable-isotopes to the study of sources and fate of metals in the environment. Environmental Science \& Technology, 42, 655-664.

Wen, X. Y., Huang, C. M., Tang, Y., Gong-Bo, S. L., Hu, X. X., \& Wang, Z. W. (2014). Rare earth elements: a potential proxy for identifying the lacustrine sediment source and soil erosion intensity in karst areas. Journal of Soils and Sediments, 14, 1693-1702.

Wethered, A. S., Ralph, T. J., Smith, H. G., Fryirs, K. A., \& Heijnis, H. (2015). Quantifying fluvial (dis)connectivity in an agricultural catchment using a geomorphic approach and sediment source tracing. Journal of Soils and Sediments, 15, 2052-2066.

Wilkinson, S. N., Wallbrink, P. J., Hancock, G. J., Blake, W. H., Shakesby, R. A., \& Doerr, S. H. (2009). Fallout radionuclide tracers identify a switch in sediment sources and transport-limited sediment yield following wildfire in a eucalypt forest. Geomorphology, 110, 140-151.

Williams, M. A., Myrold, D. D., \& Bottomley, P. J.. (2006). Carbon flow from ${ }^{13}$ C-labeled straw and root residues into the phospholipid fatty acids of a soil microbial community under field conditions. Soil Biology and Biochemistry, 38, 759-768.

Wombacker, F., Rehkaemper, M., Mezger, K., \& Muenker, C. (2003). Stable isotope composition of cadmium in geological materials and meteorites determined by multiple collector-ICPMS. Geochimica et Cosmochimica Acta, 67, 4639-4654.

Wood, P., \& Armitage, P. (1997). Biological effects of fine sediment in the lotic environment. 
Wooldridge, D. D. (1965). Tracing soil particle movement with Fe-59. Soil Science Society of America Proceedings, 29, 469-472.

Young, R. A., \& Holt, R. F. (1968). Tracing soil movement with fluorescent glass particles. Soil Science Society of America Proceedings, 32, 600-602.

Yu, L., \& Oldfield, F. (1989). A multivariate mixing model for identifying sediment source from magnetic measurements. Quaternary Research, 32, 168-181.

Zapata, F. (2003). The use of environmental radionuclides as tracers in soil erosion and

Zhang, W., Tang, X. Y., Weisbrod, N., Zhao, P., \& Reid, B. J. (2015). A coupled field study of subsurface fracture flow and colloid transport. Journal of Hydrology, 524, 476-488

Zhang, X. B., Long, Y., He, X. B., Wen, A. B., \& Yan, D. C. (2012). Use of ${ }^{137} \mathrm{Cs}$ and ${ }^{210} \mathrm{~Pb}$ ex peaks produced by events in the catchment for dating sediments in the Jiulongdian Reservoir, Cuxiong, Yunnan Province, China. In A. L. Collins, V. Golosov, A. J. Horowitz, X. X. Lu, M. Stone, D. E. Walling, et al. (Eds.), Erosion and Sediment Yields in Changing Environment (pp. 378-384) (Proceedings of an IAHS International Commission on Continental Erosion). IAHS Publication No. 356. Wallingford: IAHS Press.

Zhang, X. C., \& Liu, B. L. (2016). Using multiple composite fingerprints to quantify fine sediment source contributions: A new direction. Geoderma, 268, 108-118. 
1236

1237

1238

1239

1240

1241

1242

1243

1244

Zhang, X. C., Friedrich, J. M., Nearing, M. A., \& Norton, L. D. (2001). Potential use of rare earth oxides as tracers for soil erosion and aggregation studies. Soil Science Society of America Journal, 65, 1508-1515.

Zhang, X., Wen, Z., Feng, M., Yang, Q., \& Zheng, J. (2007). Application of ${ }^{137}$ Cs fingerprinting technique to interpreting sediment production records from reservoir deposits in a small catchment of the Hilly Loess Plateau, China. Science in China Series D: Earth Sciences, 50, 254-260.

Zhu, M. Y., Tan, S. D., Liu, W. Z., \& Zhang, Q. F. (2010). A review of REE tracer method used in soil erosion studies. Agricultural Sciences in China, 9, 1167-1174. 


\section{Figure caption:}

1246

1247 Fig. 1 A conceptual framework of integrated, spatial distributed source tracking approach for fine 1248 sediment.

1249

1250 
Table 1 A review of tracers for fine sediment tracking

\begin{tabular}{|c|c|c|c|c|c|c|c|}
\hline Category & Tracer & Origin & $\begin{array}{l}\text { Applicable } \\
\text { timeframe }\end{array}$ & $\begin{array}{l}\text { Applicable } \\
\text { spatial scale }\end{array}$ & Advantage & Limitation & Reference \\
\hline \multirow[t]{3}{*}{ Radionuclides } & ${ }^{137} \mathrm{Cs}$ & Man-made & Since 1954 & Plot to catchment & $\begin{array}{l}\text { Capable of distinguishing } \\
\text { uncultivated and cultivated } \\
\text { lands and reconstructing } \\
\text { retrospective sedimentation } \\
\text { histories }\end{array}$ & $\begin{array}{l}\text { The chronology of } \\
\text { sedimentation is crude, } \\
\text { which is separated by a } \\
\text { turning year of } 1963 \\
\text { (main peak) }\end{array}$ & $\begin{array}{l}\text { Wallbrink and } \\
\text { Murray (1993); } \\
\text { Wallbrink et al. } \\
\text { (1998); Zhang } \\
\text { et al. (2007) }\end{array}$ \\
\hline & ${ }^{7} \mathrm{Be}$ & $\begin{array}{l}\text { Natural } \\
\text { cosmogenic }\end{array}$ & $\begin{array}{l}\text { Runoff event; } \\
<5 \text { months }\end{array}$ & $\begin{array}{l}\text { Plot to short } \\
\text { reach }\end{array}$ & $\begin{array}{l}\text { Capable of estimating runoff } \\
\text { events based and seasonal } \\
\text { erosion }\end{array}$ & $\begin{array}{l}\text { Not for serious erosion, } \\
\text { gully erosion, long term } \\
\text { erosion estimation or } \\
\text { distinguishing cultivated } \\
\text { and uncultivated surface } \\
\text { soils }\end{array}$ & $\begin{array}{l}\text { Walling } \\
(2013 a)\end{array}$ \\
\hline & ${ }^{210} \mathrm{~Pb}_{\mathrm{ex}}$ & $\begin{array}{l}\text { Natural } \\
\text { geogenic }\end{array}$ & $\begin{array}{l}<\sim 100-150 \\
\text { years }\end{array}$ & Plot to catchment & $\begin{array}{l}\text { Capable of distinguishing } \\
\text { uncultivated and cultivated } \\
\text { lands and reconstructing } \\
\text { retrospective sedimentation } \\
\text { histories }\end{array}$ & $\begin{array}{l}\text { Requires skilled staff; } \\
\text { measurement with low } \\
\text { energy gamma } \\
\text { spectrometry is not easy }\end{array}$ & $\begin{array}{l}\text { Wallbrink and } \\
\text { Murray (1993); } \\
\text { Wallbrink et al. } \\
\text { (1998); Mabit } \\
\text { et al. (2008) }\end{array}$ \\
\hline $\begin{array}{l}\text { Geochemical } \\
\text { elements }\end{array}$ & $\begin{array}{l}\text { Rare earth } \\
\text { elements }\end{array}$ & $\begin{array}{l}\text { Artificially } \\
\text { added or } \\
\text { natural } \\
\text { geogenic }\end{array}$ & $\begin{array}{l}\text { Runoff event } \\
\text { (artificial) or } \\
\text { since } 1772 \\
\text { (natural) }\end{array}$ & $\begin{array}{l}\text { Laboratory and } \\
\text { pilot scale } \\
\text { (artificial); } \\
\text { catchment } \\
\text { (natural) }\end{array}$ & $\begin{array}{l}\text { Capable of estimating soil } \\
\text { redistribution at small } \\
\text { temporal and spatial scales } \\
\text { (artificial); for reconstructing } \\
\text { the histories of soil erosion } \\
\text { from deposited sediment }\end{array}$ & $\begin{array}{l}\text { Not for undisturbed soils } \\
\text { and acidic soils }\end{array}$ & $\begin{array}{l}\text { Tian et al. } \\
\text { (1994); Land et } \\
\text { al. (1999); Wen } \\
\text { et al. (2014) }\end{array}$ \\
\hline
\end{tabular}




\begin{tabular}{|c|c|c|c|c|}
\hline & Major elements & $\begin{array}{l}\text { Natural } \\
\text { geogenic }\end{array}$ & $\begin{array}{l}\text { Runoff event } \\
\text { based; < 150 } \\
\text { years }\end{array}$ & Catchment \\
\hline & Trace elements & $\begin{array}{l}\text { Natural } \\
\text { lithogenic }\end{array}$ & $\begin{array}{l}\text { Runoff event } \\
\text { based; < 150 } \\
\text { years }\end{array}$ & Catchment \\
\hline \multirow[t]{4}{*}{$\begin{array}{l}\text { Properties of } \\
\text { organic matter }\end{array}$} & $\begin{array}{l}\text { TOC, TON, } \\
\text { TOP }\end{array}$ & Plants & $\begin{array}{l}\text { Runoff event } \\
\text { based; } \\
\text { decades }\end{array}$ & Catchment \\
\hline & $\begin{array}{l}3 \mathrm{D} \\
\text { Fluorescence } \\
\text { spectroscopy }\end{array}$ & Plants & $\begin{array}{l}\text { Runoff event } \\
\text { based; } \\
\text { seasonal }\end{array}$ & Catchment \\
\hline & ${ }^{13} \mathrm{C},{ }^{15} \mathrm{~N}$ & Plants & $\begin{array}{l}\text { Runoff event } \\
\text { based; several } \\
\text { hundred years }\end{array}$ & Catchment \\
\hline & $\begin{array}{l}\mathrm{CSSI}\left({ }^{13} \mathrm{C} \text { of }\right. \\
\text { fatty acids })\end{array}$ & $\begin{array}{l}\text { Plants } \\
\text { (including } \\
\text { crops) }\end{array}$ & $\begin{array}{l}\text { Runoff event- } \\
\text { based; } \\
\text { seasonal; } \\
\text { decades to } \\
\text { thousands of } \\
\text { years }\end{array}$ & Catchment \\
\hline $\begin{array}{l}\text { Anthropogenic } \\
\text { pollutants }\end{array}$ & Heavy metals & $\begin{array}{l}\text { Industry } \\
\text { and }\end{array}$ & $\begin{array}{l}\text { Rain event } \\
\text { based; }\end{array}$ & Catchment \\
\hline
\end{tabular}

(natural)

Applicable in catchments showing significant spatial variations in geochemistry Applicable in catchments showing significant spatial variations in lithology

Capable of distinguishing different land-uses

Capable of distinguishing different types or quality of organic matter sources

Capable of distinguishing different land-uses and land covers

Capable of distinguishing between land-uses and cropping systems

Capable of reconstructing sedimentation rates in
Not for catchments with spatially homogeneous geochemistry

Not for catchments with spatially homogeneous lithology

Relatively low discriminatory ability for statistics

Not standalone

Not standalone; not for situations where the soil is very low in organic matter

May be limited by mixed or unknown sources of
Rollinson

(1993); Franz

et al. (2013)

Collins et al.

(1997a);

Grimes et al.

(2007)

Walling and

Amos (1999);

Carter et al.

(2003)

Larsen et al.

Fox and

Papanicolaou

Gibbs (2008)

Chillrud et al. (2003); Franz 


$\begin{array}{llll} & \text { agriculture } & \begin{array}{l}\text { seasonal; } \\ \text { decades }\end{array} & \\ \begin{array}{l}\text { Persistent } \\ \text { organic }\end{array} & \begin{array}{l}\text { Industry } \\ \text { and }\end{array} & \begin{array}{l}\text { Seasonal; } \\ \text { decades }\end{array} & \text { Catchment } \\ \text { pollutants } & \text { agriculture } & \\ \text { Pesticides } & \text { Agriculture } & \begin{array}{l}\text { Seasonal; } \\ \text { decades }\end{array} & \text { Catchment } \\ & & \begin{array}{l}\text { Seasonal; } \\ \text { decades }\end{array} & \text { Catchment } \\ { }^{114} \mathrm{Cd},{ }^{65} \mathrm{Cu}, & \text { Industry } & \\ { }^{202} \mathrm{Hg},{ }^{66} \mathrm{Zn} & & \end{array}$

floodplains \& catchments

Decades;

runoff event

based

magnetic

properties ( $x_{\mathrm{If}}$,

$\chi_{\mathrm{fd}}, \chi_{\text {ARM }}$,

SIRM,

Soft IRM,

HIRM)

Physical

properties
Color signature Natural

Decades; Catchment
runoff event
based

having historic river pollution

Capable of identifying

agricultural sources

Capable of tracking crop-

specific agricultural sources

Capable of tracking industry-

affected sources

events

each metal

et al. (2013)

Not for individual runoff

events

Helm et al.

(2011)

Not for individual runoff

events

Tang et al.

(2014)

Gao et al.

(2008); Weiss

et al. (2008);

Petit et al.

(2008); Mil-

Homens et al.

(2013)

$\mathrm{Yu}$ and Oldfield (1989); Walden

et al. (1997);

van der Waal et

al. (2015)

$\begin{array}{ll}\text { Quickly, easily measurable } & \text { May be subject to } \\ \text { moisture content and } \\ \text { chemical reactions }\end{array}$

Krein et al.

(2003); Pulley and Rowntree

(2016) 


\begin{tabular}{|c|c|c|c|c|c|c|c|}
\hline & $\begin{array}{l}\text { Particle size } \\
\text { distribution }\end{array}$ & Natural & $\begin{array}{l}\text { Decades; } \\
\text { runoff event } \\
\text { based }\end{array}$ & Catchment & Easily measurable & $\begin{array}{l}\text { Relatively low } \\
\text { discriminatory ability }\end{array}$ & $\begin{array}{l}\text { Collins et al. } \\
\text { (1997b) }\end{array}$ \\
\hline \multirow[t]{2}{*}{ Other tracers } & $\begin{array}{l}\text { Fluorescent } \\
\text { fine sediment } \\
\text { surrogate }\end{array}$ & Artificial & $\begin{array}{l}\text { Runoff event } \\
\text { based }\end{array}$ & Slope & $\begin{array}{l}\text { Results are precise with high } \\
\text { spatial resolution }\end{array}$ & $\begin{array}{l}\text { Relatively costly and } \\
\text { man-power demanding }\end{array}$ & $\begin{array}{l}\text { Harvey et al. } \\
\text { (2012) }\end{array}$ \\
\hline & $\begin{array}{l}\text { Radioisotope- } \\
\text { tagged particles }\end{array}$ & Artificial & $\begin{array}{l}\text { Runoff event } \\
\text { based }\end{array}$ & Slope & $\begin{array}{l}\text { Results are precise with high } \\
\text { spatial resolution }\end{array}$ & $\begin{array}{l}\text { Relatively costly; needs } \\
\text { radioisotope permits and } \\
\text { related facilities. }\end{array}$ & $\begin{array}{l}\text { Wooldridge } \\
(1965) ; \\
\text { Newbold et al. } \\
\text { (2005); } \\
\text { Greenwood } \\
(2012)\end{array}$ \\
\hline
\end{tabular}

